\title{
A revision of the endemic Malagasy genus Beguea (Sapindaceae)
}

\author{
George E. Schatz, Roy E. Gereau \& Porter P. Lowry II
}

\begin{abstract}
SCHATZ, G.E., R.E. GEREAU \& P.P. LOWRY II (2017). A revision of the endemic Malagasy genus Beguea (Sapindaceae). Candollea $72: 45-65$. In English, English and French abstracts. DOI: http://dx.doi.org/10.15553/c2017v721a6

A taxonomic revision of the endemic Malagasy genus Beguea Capuron (Sapindaceae) is presented. While Capuron in 1969 originally recognized a single, variable species (Beguea apetala Capuron), a careful reevaluation of all available material allows us to recognize ten species, nine of which are described as new, on the basis of numerous floral and vegetative characters. Material of only two of the new species was available to Capuron, and was included in his broad circumscription of Beguea apetala, whereas all material of the remaining seven new species has been collected since 1992. The nine species are illustrated by line drawings, and several species are documented by field photographs. The geographic distribution of each species is presented and mapped, and a preliminary risk of extinction assessment is provided using the IUCN Red List criteria.
\end{abstract}

\section{Résumé}

SCHATZ, G.E., R.E. GEREAU \& P.P. LOWRY II (2017). Une révision du genre Beguea (Sapindaceae), endémique de Madagascar. Candollea 72 : 45-65. En anglais, résumé anglais et français. DOI: http://dx.doi.org/10.15553/c2017v721a6

Une révision taxonomique du genre Beguea Capuron (Sapindaceae), endémique de Madagascar est présentée. Capuron n'avait reconnu qu'une seule espèce variable (Beguea apetala Capuron) en 1969 mais une réévaluation détaillée de l'ensemble du matériel disponible nous permet de reconnaître dix espèces dont neuf décrites comme nouvelles, basées sur de nombreux caractères floraux et végétatifs. Capuron avait à sa disposition des échantillons appartenant à seulement deux des nouvelles espèces, qu'il avait inclus dans sa délimitation de Beguea apetala tandis que tout le matériel des sept autres nouveautés a été récolté depuis 1992. Les neuf nouvelles espèces sont illustrées par des dessins au trait et plusieurs sont documentées par des photos prises sur le terrain. La distribution géographique de chaque espèce est présentée et cartographiée, ainsi qu'une évaluation du risque d'extinction selon les critères de la Liste Rouge de l'UICN.

\section{Keywords}

SAPINDACEAE - Beguea - Madagascar - Conservation - New species

\footnotetext{
Addresses of the authors:
}

GES, REG : Africa and Madagascar Program, Missouri Botanical Garden, P.O. Box 299, St. Louis, MO 63166-0299, U.S.A. E-mail: george.schatz@mobot.org PPL: Africa and Madagascar Program, Missouri Botanical Garden, P.O. Box 299, St. Louis, MO 63166-0299, U.S.A. and Institut de Systématique, Evolution, et Biodiversité (UMR 7205 - CNRS MNHN UPMC EPHE), Muséum national d'Histoire naturelle, Sorbonne Universités, C.P. 39, rue Cuvier 57, 75231 Paris CEDEX 05, France 


\section{Introduction}

After more than 20 years of careful field observations, René Capuron published his monumental Révision des Sapindacées de Madagascar et des Comores (CAPURon, 1969), in which he enumerated 108 specific and infraspecific taxa of Sapindaceae in Madagascar and the Comoro Islands, all of which he had seen as living plants. Among the four new genera and 40 new species described therein was the genus Beguea Capuron with its single species, $B$. apetala Capuron. Recent phylogenetic studies of Sapindaceae (BUER KI et al., 2009, 2010, 2014) have suggested that Beguea belongs in a clade informally referred to as the Macphersonia group, which includes other endemic Malagasy genera (Chouxia Capuron, Conchopetalum Radlk., Gereaua Buerki \& Callm., Plagioscyphus Radlk., Pseudopteris Baill., and Tsingya Capuron) as well as eastern and southern African Pappea Eckl. \& Zeyh. and East African/Comorian/ Malagasy Macphersonia Blume. Within the Macphersonia group, Beguea is part of an unresolved clade ("clade B") that also includes Chouxia, Conchopetalum, Gereaua, Macphersonia, and Pseudopteris; Beguea can be distinguished from all of the other genera in the clade by its apetalous flowers. Although Tsingya (in "clade A" with Pappea and Plagioscyphus) also exhibits apetalous flowers, it differs from Beguea by its monoecious sexual system (vs dioecious in Beguea), flattened, irregularly lobed disc (vs cushion-shaped), stamens inserted into deep holes in the disc (vs stamens inserted interior to the disc), and pear-shaped fruits densely covered with stellate indument (vs spheroid to ellipsoid to obovoid, glabrous or glabrescent fruit) (Buerki et al., 2014; Schatz, 2001). A reevaluation of the character variation in Beguea, especially regarding indument, leaf size, and various aspects of the leaflets, leads us to recognize a total of 10 species, nine of which are described as new. Although material of two of the new species (B. birkinshawii G.E. Schatz et al. and B. vulgaris G.E. Schatz et al.) was available to Capuron but included within his broad concept of $B$. apetala, all material of the remaining seven new species has been gathered since 1992, resulting in a much better understanding of the overall variation in vegetative, floral, and fruit characters within the genus.

A full listing of exsiccatae for each species, with complete localities and latitude/longitude coordinates, as well as images of selected taxa, are available through the Madagascar CATALOGUE (2016). Geographic coordinates indicated in square brackets were assigned post facto using available information on Malagasy place names and topographic maps, compiled as a gazetteer of botanical collecting localities in Madagascar [http://mobot.org/MOBOT/research/madagascar/gazetteer].

\section{Taxonomic treatment}

Beguea Capuron in Mém. Mus. Natl. Hist. Nat., B, Bot. 19: 105.1969.

Typus: Beguea apetala Capuron.

Dioecious small to large trees with simple or rarely stellatefasciculate indument. Leaves alternate, trifoliolate or paripinnately compound with 4-30 alternate to subopposite, entire leaflets, the rachis usually extending slightly beyond the terminal leaflet giving the impression of an aborted leaflet; pseudostipules absent. Inflorescences axillary, sometimes borne on stems below the leaves (ramiflorous), long racemose. Flowers actinomorphic; calyx united basally, (5-)6-7(-8)-lobed; petals absent; disc cushion-shaped, the margin sinuate; stamens 6-8(-10), filaments long, slender, anthers ovate to oblong, laterally dehiscent; staminodia in female flowers resembling short stamens; ovary 3-locular, style longer than the ovary, dividing apically into 3 distinct stigmas, ovule 1 per locule; pistillode in male flowers minute. Fruit indehiscent, globose to obovoid, 1-seeded, dry to somewhat fleshy or woody, crowned by the apiculate remnant of the style; seed surrounded by a translucent, fleshy arillode, the hilar scar basal, the cotyledons highly ruminate.

Notes. - A genus of ten species, occurring in humid and subhumid forest, rarely in dry forest. The genus name honors the French botanist Louis H. Bégué, who founded the Service Forestier collection series in Madagascar.

\section{Key to the species of Beguea}

1. Apex of leaflets retuse to deeply emarginate; fruit with mesocarp 3-4.7 mm thick; Andohahela PN. 3. B. australis

1a. Apex of leaflets rounded to acute or acuminate; fruit with mesocarp (when known) less than $2 \mathrm{~mm}$ thick ............. 2

2. Petiole and leaf rachis covered with tufts of very short golden stellate-fasciculate trichomes............................... 3

2a. Petiole and leaf rachis glabrous or with persistent indument of simple trichomes.

3. Apex of leaflets acute to acuminate and short-mucronate, the lamina densely punctate above, the margin slightly revolute; inflorescences unbranched........ 7. B. galokensis

3a. Apex of leaflets rounded, not mucronate, the lamina not punctate above, the margin strongly revolute; inflorescences sometimes branched. 4. B. betamponensis

4. Petiole and leaf rachis with dense persistent indument... 5

4a. Petiole and leaf rachis glabrous or initially with sparse indument, then glabrescent... 9

5. Leaflets conduplicate, usually folded along the midvein in pressed material. 6

5a. Leaflets flat in pressed material....................................... 7 
6. Leaflets 3-14, the base markedly asymmetrical, the margins usually strongly revolute, secondary veins 8-15 per side; widespread, Manakara S to Farafangana...... 2. B. apetala

6a. Leaflets 4-6, the base symmetrical, the margins flat and minutely thickened but not revolute, secondary veins 7-10 per side; Montagne des Français.

6. B. borealis

7. Leaflets $6-8$, the apex distinctly acuminate, the acumen acute; pedicels c. $1 \mathrm{~mm}$ long; anthers 2.2-2.5 mm long; Ankerana

\section{B. ankeranensis}

7a. Leaflets 7-16, the apex acute or acuminate, the acumen rounded to irregularly or slightly retuse; pedicels $2.5-4 \mathrm{~mm}$ long; anthers c. $1 \mathrm{~mm}$ long

\section{8}

8. Leaflets with secondary veins emerging at a $45^{\circ}$ angle to the midvein; inflorescence densely light reddish chocolate tomentose; pedicels slender, $0.2-0.5 \mathrm{~mm}$ in diam. in flower, sparsely light chocolate tomentulose, $0.9-1 \mathrm{~mm}$ in diam. in fruit, glabrous; sepals c. $0.5 \mathrm{~mm}$ long; fruit $1.7-1.8 \mathrm{~cm}$ long, c. $1.2 \mathrm{~cm}$ in diam., ellipsoid to obovoid; Lokobe PA

\section{B. birkinshawii}

8a. Leaflets with secondary veins emerging at a $25^{\circ}$ angle to the midvein; inflorescence densely ferruginous tomentose; pedicels stout, $0.7-0.9 \mathrm{~mm}$ in diam. in flower, densely ferruginous tomentose, $1.3-1.5 \mathrm{~mm}$ in diam. in fruit; sepals c. $1.5 \mathrm{~mm}$ long; fruit $2.3-2.8 \mathrm{~cm}$ in diam., spheroid; Andohahela, Ranomafana and "Corridor forestier MarojejyAnjanaharibe Sud-Tsaratanana Nord”. 9. B. turkii

9. Leaflets with a flat margin; calyx glabrous; Tsaratanana PA. 8. B. tsaratananensis

9a. Leaflets with a revolute margin; calyx sparsely puberulous outside; widespread, Marojejy PA S to Bemangidy ( $\mathrm{N}$ of Tolagnaro) 10. B. vulgaris

1. Beguea ankeranensis G.E. Schatz \& Lowry, spec. nova (Fig. 1, 2A).

Typus : Madagascar. Prov. Toamasina : Atsinanana Region, Brickaville, Anjahamamay, Anivoranokely, Ankerana forest, $18^{\circ} 24^{\prime} 21^{\prime \prime S} 48^{\circ} 48^{\prime} 18^{\prime} \mathrm{E}, 700 \mathrm{~m}, 19 . \mathrm{I} .2012$, fl., Antilabimena 7978 (holo- : MO-6704230!; iso- : G [G00341688]!, K!, P [P00580357]! TAN).

Haec species a congeneris foliorum petiolo rhachideque indumento aureobrunneo tomentulosis, foliolis 6 ad 8 in sicco complanatis apice acute acuminatis, pedicellis c. $1 \mathrm{~mm}$ longis atque antheris 2.2-2.5 $\mathrm{mm}$ longis distinguitur.

Tree c. $15 \mathrm{~m}$ tall; stems densely golden brown tomentulose. Petioles 2.6-4 cm, densely golden brown tomentulose. Leaves with 6-8 subopposite to alternate leaflets; rachis $3.8-7 \mathrm{~cm}$, keeled above, golden brown tomentulose; petiolule $2.5-3 \mathrm{~mm}$, golden brown tomentulose; leaflet blade $2.8-7 \times 1.2-2.2 \mathrm{~cm}$, elliptic, papyraceous to subcoriaceous, flat in pressed material, glabrous and only slightly glossy above, sparsely light brown tomentulose on midvein and secondary veins below, base weakly to markedly asymmetrical, acute to nearly decurrent, margins minutely thickened, not revolute, apex distinctly acuminate, the acumen acute, midvein distinctly raised and knife-like above and below, secondary veins (8-)10-13 per side, flat to slightly impressed above, raised below, tertiary venation obscure above, slightly raised and evident below. Inflorescence axis 16-19 cm long, c. $1 \mathrm{~mm}$ in diam., unbranched, dark chocolate brown, densely golden brown tomentulose; bracts c. $1 \mathrm{~mm}$, narrowly triangular, adaxially concave; pedicels c. $1 \mathrm{~mm}$, c. $0.8 \mathrm{~mm}$ in diam., densely golden brown tomentulose. Male flowers with a shallowly cupulate, (4-)5-lobed calyx, the lobes broadly triangular, c. $1 \times 1.2 \mathrm{~mm}$, acute, densely golden brown tomentulose outside, densely golden setaceous inside; stamens 8, filaments 1-3 mm, glabrous, anthers 2.2-2.5 $\times$ c. $0.8 \mathrm{~mm}$, ellipsoid; disc and pistillode densely golden setaceous, the trichomes to $0.5 \mathrm{~mm}$. Female flowers not seen. Fruit not seen.

Conservation status. - Known only from a single collection from well within an intact forest block of the newly designated Corridor Ankeniheny Zahamena PA (Fig. 3), and lacking any additional information on population size, $B$. ankeranensis is assigned a provisional status of "Least Concern" [LC] using the IUCN Red List Criteria (IUCN, 2012), with the caution that this status is highly dependent on continued effective protection.

Notes. - Beguea ankeranensis is known only from the type collection in humid forest at Ankerana (Fig. 3), which is included within the recently decreed Corridor Ankeniheny Zahamena PA. It can be easily distinguished from the two species most similar morphologically (B. birkinshawii and $B$. turkii) by its leaflets with a long-acuminate apex and an acute acumen (vs acute to short acuminate apex and rounded to retuse acumen), short pedicels c. $1 \mathrm{~mm}$ long (vs $2.5-4 \mathrm{~mm}$ long), and large anthers 2.2-2.5 $\mathrm{mm}$ long (vs only $1 \mathrm{~mm}$ long) (Fig. 1, 2A).

2. Beguea apetala Capuron in Mém. Mus. Natl. Hist. Nat., B, Bot. 19: 105. 1969 (Fig. 2B).

Lectotypus (designated here) : Madagascar. Prov. Toamasina: Analanjirofo Region, env. de la baie d'Antongil: massif de l'Ambohitsitondroina de Mahalevona, [15 $25^{\circ} \mathrm{S}$ 49 58'E], c. 700 m, XII.1953, fl., Service Forestier 8701 (lecto- : P [P00214641]!; isolecto- : G [G00341689]!, K!, L!, MO-6701278!, P [P00137008, P00137009, P00580342]!, TEF [TEF000464]!). 

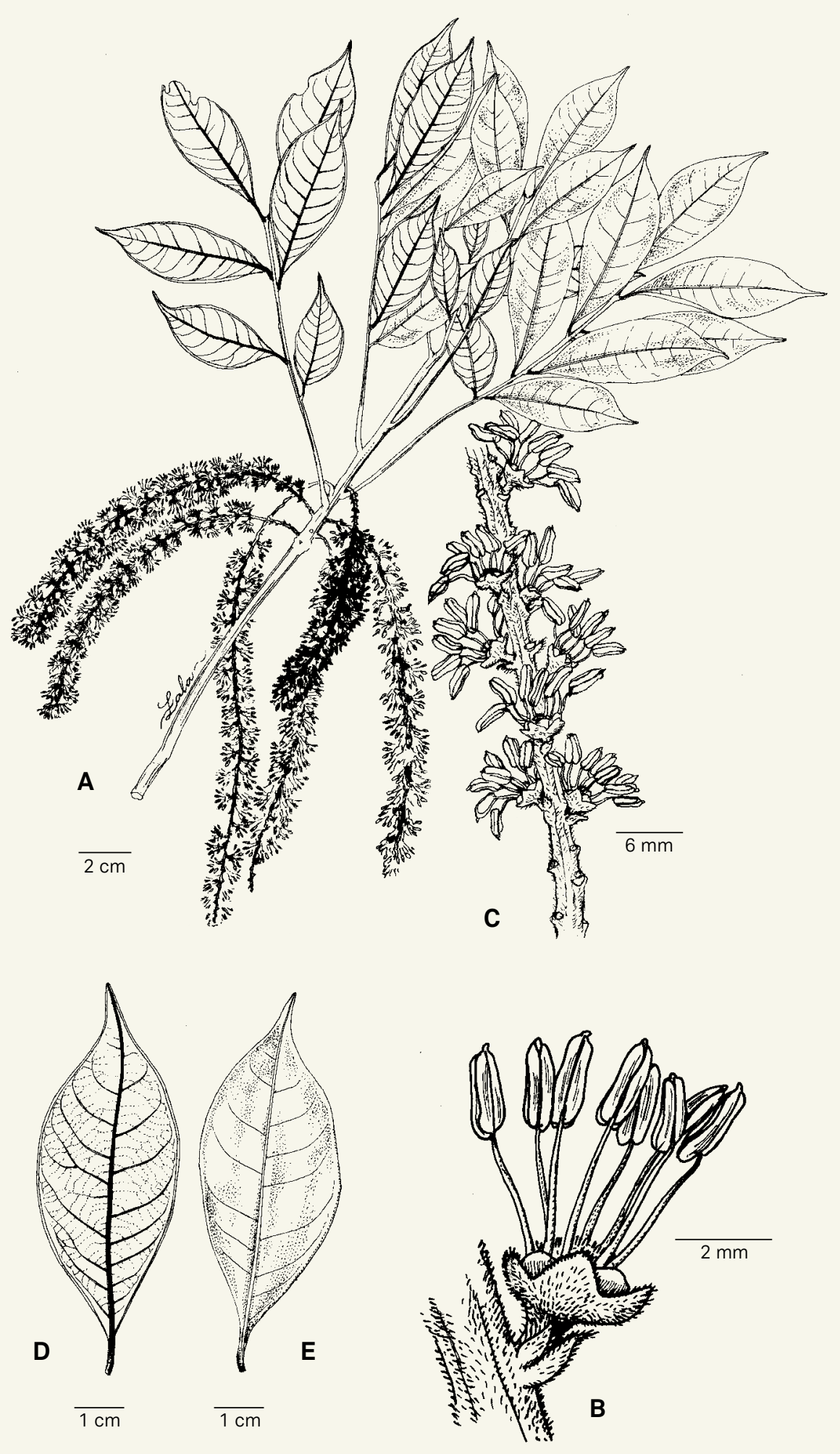

Fig. 1. - Beguea ankeranensis G.E. Schatz \& Lowry. A. Flowering branch; B. Detail of flower at anthesis; C. Portion of inflorescence axis; D. Leaflet (lower surface); E. Leaflet (upper surface). [Antilahimena 7978, MO] [Drawing: R.L. Andriamiarisoa] 

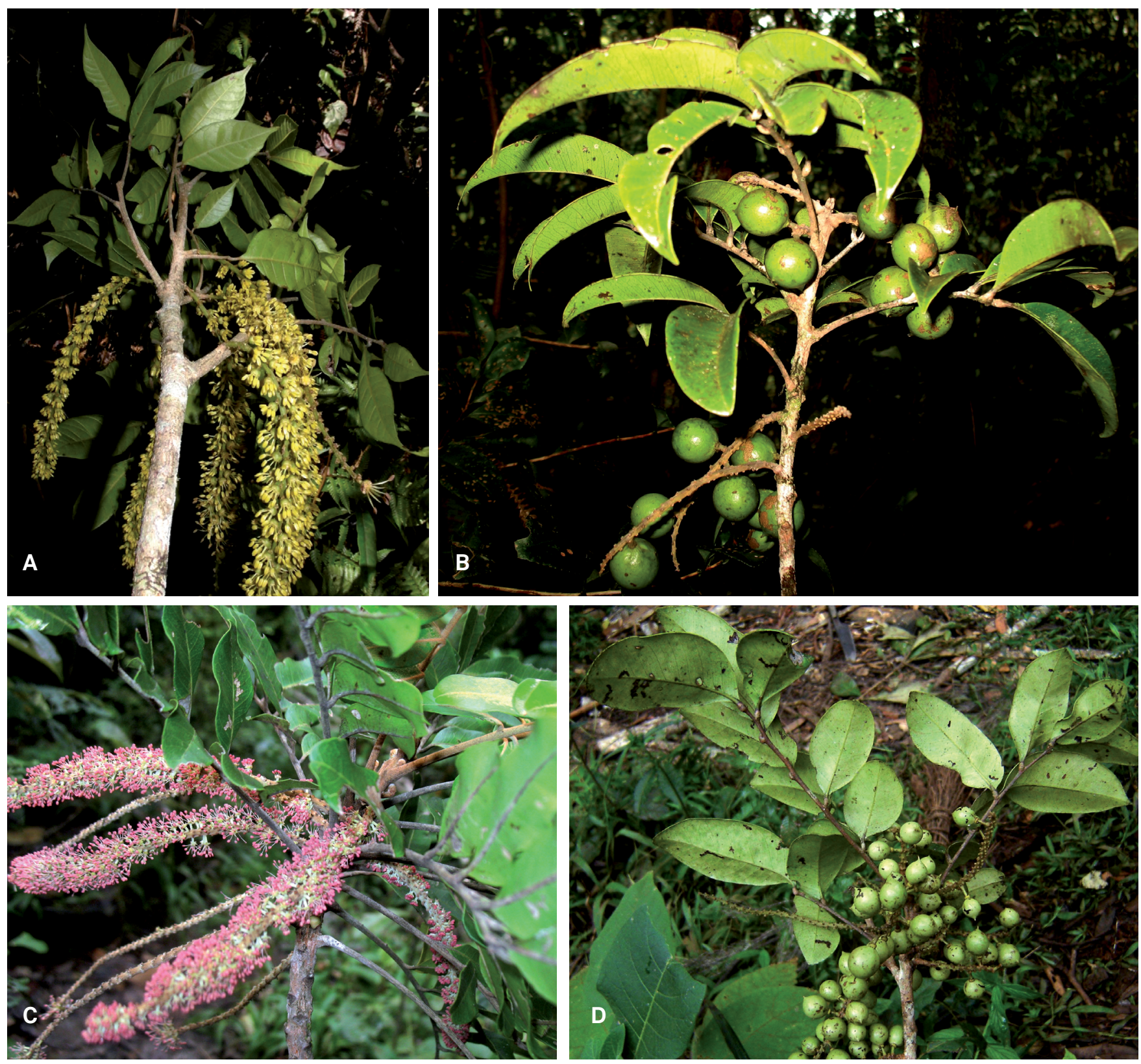

Fig. 2. - Photographs of Beguea Capuron. A. Beguea ankeranensis G.E. Schatz \& Lowry; B. Beguea apetala Capuron; C. Beguea turkii G.E. Schatz, Gereau \& Lowry; D. Beguea vulgaris G.E. Schatz, Gereau \& Lowry.

[A: Antilahimena 7978; B: Ravelonarivo 3854; C: Rakotovao 3648; D: Antilahimena 5459] [Photos: A, C: P. Antilahimena; B: D. Ravelonarivo; C: C. Rakotovao] 


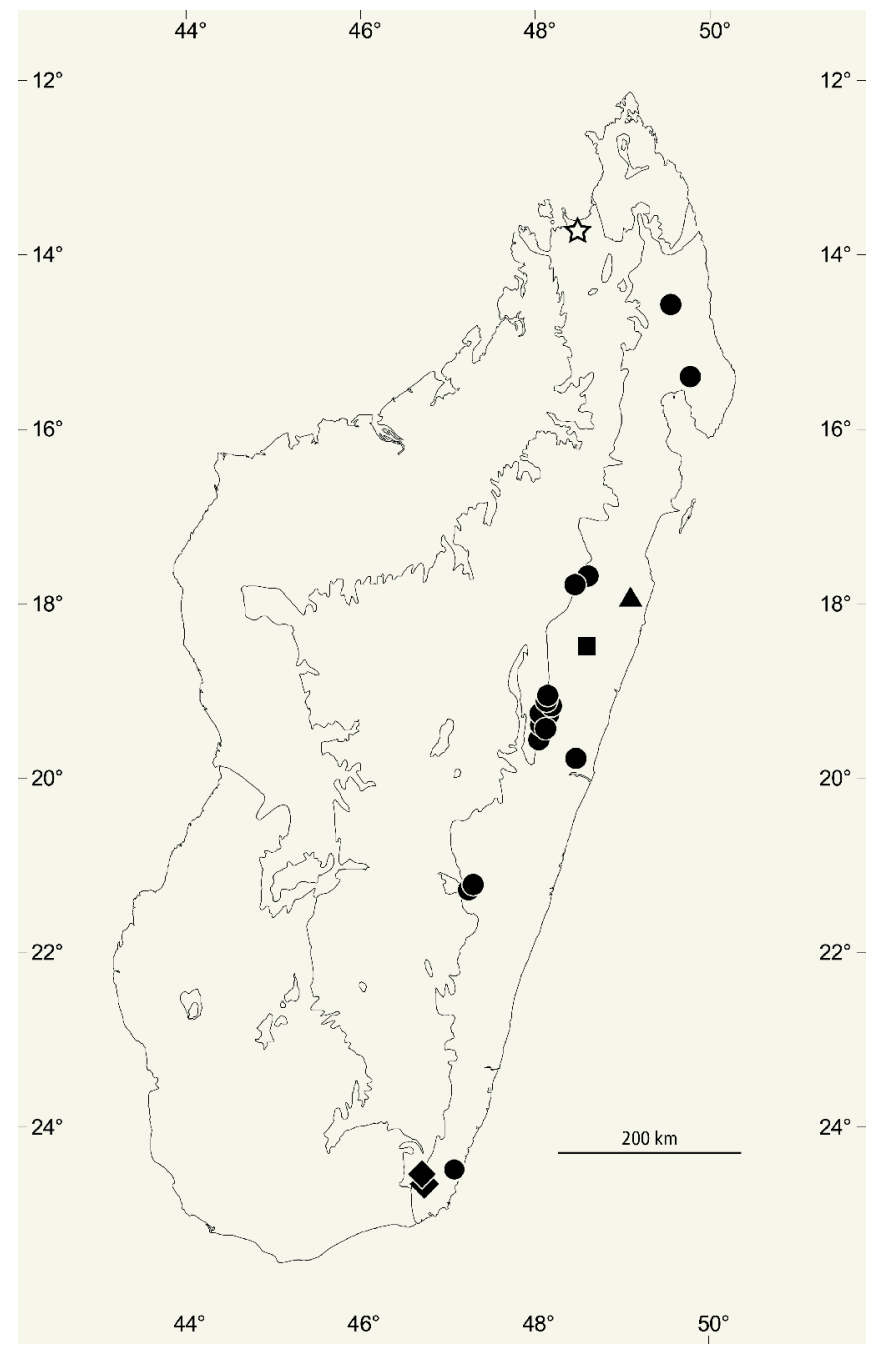

Fig. 3. - Geographic distribution of Beguea ankeranensis G.E. Schatz \& Lowry (square), B. australis G.E. Schatz, Gereau \& Lowry (diamond), B. betamponensis G.E. Schatz, Gereau \& Lowry (triangle), B. galokensis G.E. Schatz \& Lowry (star) and B. vulgaris G.E. Schatz, Gereau \& Lowry (circles), mapped on the bioclimatic zones of Madagascar (after CORNET, 1974; see SCHATZ, 2000).

Tree to $25 \mathrm{~m}$ tall; stems densely golden to whitish tomentulose, glabrescent. Petioles $2.5-12.5 \mathrm{~cm}$, densely golden tomentulose. Leaves trifoliolate or with 4-14 subopposite to opposite leaflets; rachis $1-19.8 \mathrm{~cm}$, not keeled, densely golden tomentulose; petiolule $2-9 \mathrm{~mm}$, sparsely short white sericeous, glabrescent; leaflet blade 3-15.7 × 1.9-5 cm, elliptic to ovate, subcoriaceous to coriaceous, nearly always conduplicate and folded along the midvein in pressed material, glabrous and glossy above, glabrous below except very sparsely tomentulose at the base, base markedly asymmetrical, cuneate to acute and decurrent along petiolule, margins usually strongly revolute, apex acute to usually long acuminate, the acumen rounded and sometimes minutely emarginate, usually deformed in the process of pressing, midvein slightly raised above and below, secondary veins $8-15$ per side, often not very evident below, flat to slightly raised above and below, tertiary venation evident and raised above. Inflorescence axis $2.3-33 \mathrm{~cm}$ long, 1-2 mm in diam. at base, unbranched, sparsely tan sericeous; bracts c. $0.2 \mathrm{~mm}$, triangular, adaxially concave; pedicels usually paired on a common peduncle to $1.0 \mathrm{~mm}$, sometimes solitary and epedunculate, $1.5-3.5 \mathrm{~mm}$, c. $0.4 \mathrm{~mm}$ in diam., elongating to $6 \mathrm{~mm}$ in fruit, moderately to densely golden sericeous. Male flowers with a cupulate, 5 - to 7-lobed calyx, the lobes $0.2-0.3 \times$ 0.3-0.6 mm, broadly triangular, sparsely tan sericeous outside; disc $1.2 \mathrm{~mm}$ in diam., sparsely whitish granular-farinose; stamens 8 (or 9), filaments c. $2 \mathrm{~mm}$, with sparse spreading trichomes along basal third, anthers $0.7-0.8 \times 0.3-0.4 \mathrm{~mm}$, oblong; pistillode $0.2-0.3 \mathrm{~mm}$ high, $0.2-0.3 \mathrm{~mm}$ in diam., hemispherical, covered with short appressed trichomes. Female flowers not seen. Fruit spheroid, 1.5-1.8 cm in diam., glabrescent, apex apiculate, fruit wall 0.6-0.8 $\mathrm{mm}$ thick; seed flattened ellipsoid, c. $14 \times 9 \times 7 \mathrm{~mm}$.

Additional material examined. - Madagascar. Prov. Antsiranana : SAVA Region, Forêt d'Andrakaraka, au SSW d'Antalaha, [14 $53^{\circ} \mathrm{S} 50^{\circ} 15^{\prime} \mathrm{E}$ ], 22.IX.1954, fr., Service Forestier 9233 (MO, P,TEF); env. de Lohanantsahabe (haut Antsahabe, affluent rive gauche de la Lokoho) entre Sambava et Andapa,

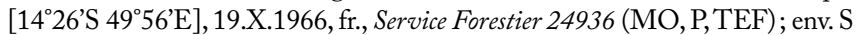
de Tsaratanana, entre Nosiarina et Antsirabe-Nord (route Sambava-Vohemar), [1406'15"S 5000'45"E], 1.IV.1967, fl., Service Forestier 27655 (MO, P,TEF). Prov. Fianarantsoa: Atsimo-Atsinanana Region, vestiges de forêts entre Fara-

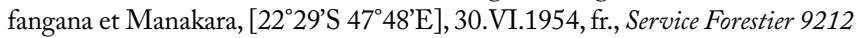
(MO, P, TEF). Prov. Toamasina: Atsinanana Region, Betampona, 17 $55^{\circ} 16^{\prime \prime}$ S 49¹2’33”E, 300 m, 20.XI.2005, fr., Buerki 149 (G, MO); Alaotra-Mangoro Region, Zahamena PN, forêt d'Ambavala, à $5 \mathrm{~km}$ au SE du village d'Ankosy, 17'32'32"S 48 43'30"E, 1250 m, 30.XI.2002, fl., Randrianjanaka 756 (CNARP, G, L, MO, P,TAN); Atsinanana Region, Maroseranana, Ambodilendemy, forêt de Vohimanana, 18²4'33"S 4847’33”E, 1155 m, 25.III.2011, fr., Ravelonarivo et al. 3854 (G, MO, P, TAN); Analanjirofo Region, de la baie d'Antongil, massif de Farankaraina, entre Navana et Andranofotsy, [15 23'S 49 $51^{\circ} \mathrm{E}$ ], 20.IX.1957, fr., Service Forestier 18347 (P, TEF).

\section{Vernacular names. - "Fandifiana", "Somotrorana".}

Conservation Status. - Beguea apetala is known from eight widely dispersed localities from between Farafangana and Manakara to north of Sambava (Fig. 4). Its geographic range comprises an extent of occurrence (EOO) of $26,017 \mathrm{~km}^{2}$ and an area of occupancy (AOO) possibly greater than $2,000 \mathrm{~km}^{2}$ given the amount of potential suitable habitat within the EOO, and it is present in two protected areas, Betampona Strict Nature Reserve and Masoala National Park. Continuing decline in habitat quality as a result of ongoing forest exploitation and clearing for agriculture at unprotected sites is projected. As the threshold for "Vulnerable" [VU] is nearly met with respect to EOO, we therefore assign a preliminary assessment of "Near Threatened" [NT] using the IUCN Red List Criteria (IUCN, 2012). 


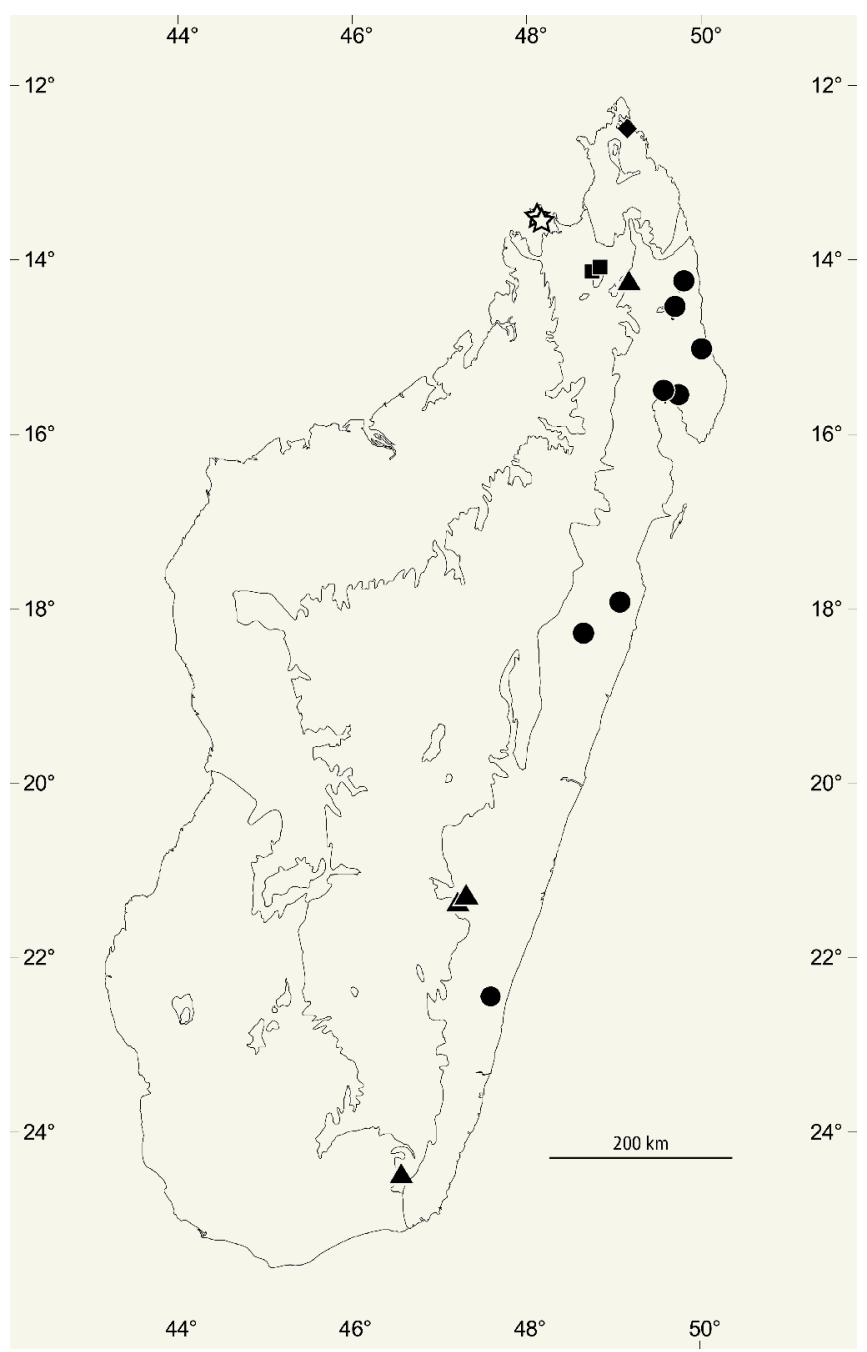

Fig. 4. - Geographic distribution of Beguea apetala Capuron (circles), B. birkinshawii G.E. Schatz, Gereau \& Lowry (stars), B. borealis G.E. Schatz \& Lowry (diamond), B. tsaratananensis G.E. Schatz, Gereau \& Lowry (squares) and B. turkii G.E. Schatz, Gereau \& Lowry (triangles), mapped on the bioclimatic zones of Madagascar (after CORNET, 1974; see ScHATZ, 2000).

Notes. - Beguea apetala is here restricted to material matching the type, with leaflets that are glabrous except at the very base beneath, are noticeably conduplicate in living material (Fig. 2B) and thus usually folded on herbarium specimens, and have revolute margins and raised tertiary venation above, as well as a distinctly long acuminate apex that is deformed to one side in the process of pressing the specimens. The number of leaflets is quite variable, ranging from 3 to 14 .

\section{Beguea australis G.E. Schatz, Gereau \& Lowry, spec. nova} (Fig. 5).

Typus: Madagascar. Prov. Toliara: Anosy Region, RNI Andohahela, Parcelle 1, Ambahibe, Isaka Ivondro, $24^{\circ} 47^{\prime} \mathrm{S}$ $46^{\circ} 50^{\prime} \mathrm{E}, 0-500$ m, 10-27.IX.1993, fr., Randriamampionona 633 (holo-: MO-6641487!; iso- : BM!, C!, CAS!, E!, G [G00341687]!, K!, L!, M!, NY!, P [P00580343]!, PRE!, TAN!, UPS!, US!).

Haec species a congeneris foliolis ad apicem retusis usque profunde emarginatis atque fructu lignoso mesocarpio 3-4.7 mm crasso distinguitur.

Tree to $20 \mathrm{~m}$ tall, bole c. $20 \mathrm{~cm}$ in diam.; stems densely light reddish tan tomentose. Petioles 7.5-10 cm, densely light reddish tan tomentose. Leaves with 12-30 alternate to subopposite leaflets; rachis $18-21 \mathrm{~cm}$, densely light reddish tan tomentulose, not keeled; petiolule 2-7 mm, densely light reddish tan tomentulose; leaflet blade 4.6-12.6 × 2.4-4.4 cm, elliptic to narrowly obovate, chartaceous to subcoriaceous, flat in pressed material, glabrous and somewhat glossy and verrucose above, initially reddish tomentulose below, glabrescent or indument persistent close to the midvein below, base asymmetrical, cuneate to attenuate and decurrent along petiolule, margins flat, apex retuse to deeply emarginate, the notch to $1 \mathrm{~cm}$ deep and often with straight sides ("v"-notched), midvein flat to raised towards the base above, initially densely light brown tomentulose, glabrescent, distinctly raised below, persistently light reddish brown tomentulose, secondary veins 8-13 per side, slightly raised above and below, initially reddish tomentulose below, glabrescent, tertiary venation slightly raised above and below. Flowers unknown. Infructescence axis 5.6-15.4 cm long, 2.8-3.5 $\mathrm{mm}$ in diam., unbranched, densely light reddish tan tomentose; pedicels in fruit 3-4 mm, c. $1.1 \mathrm{~mm}$ in diam., reddish tomentulose. Fruit ellipsoid, $1.4-3.1 \mathrm{~cm}$ long, $1.1-2.3 \mathrm{~cm}$ in diam, glabrous, apex acute and slightly curved, sometimes with an apiculum to $1 \mathrm{~mm}$, mesocarp (fruit wall) 3-4.7 $\mathrm{mm}$ thick, rendering the fruits hard and woody; seed flattened ellipsoid, 5-17 $\times$ c. $13 \times$ c. $12 \mathrm{~mm}$.

Etymology. - The epithet australis refers to the southernmost occurrence of the genus Beguea in Madagascar.

Conservation status. - Despite the very restricted Area of Occupancy within well-protected Andohahela National Park (Fig. 4), there appear to be no current threats, and thus Beguea australis is assigned a status of "Least Concern" [LC] using the IUCN Red List Criteria (IUCN, 2012), with the caution that this status is highly dependent on continued effective protection. 


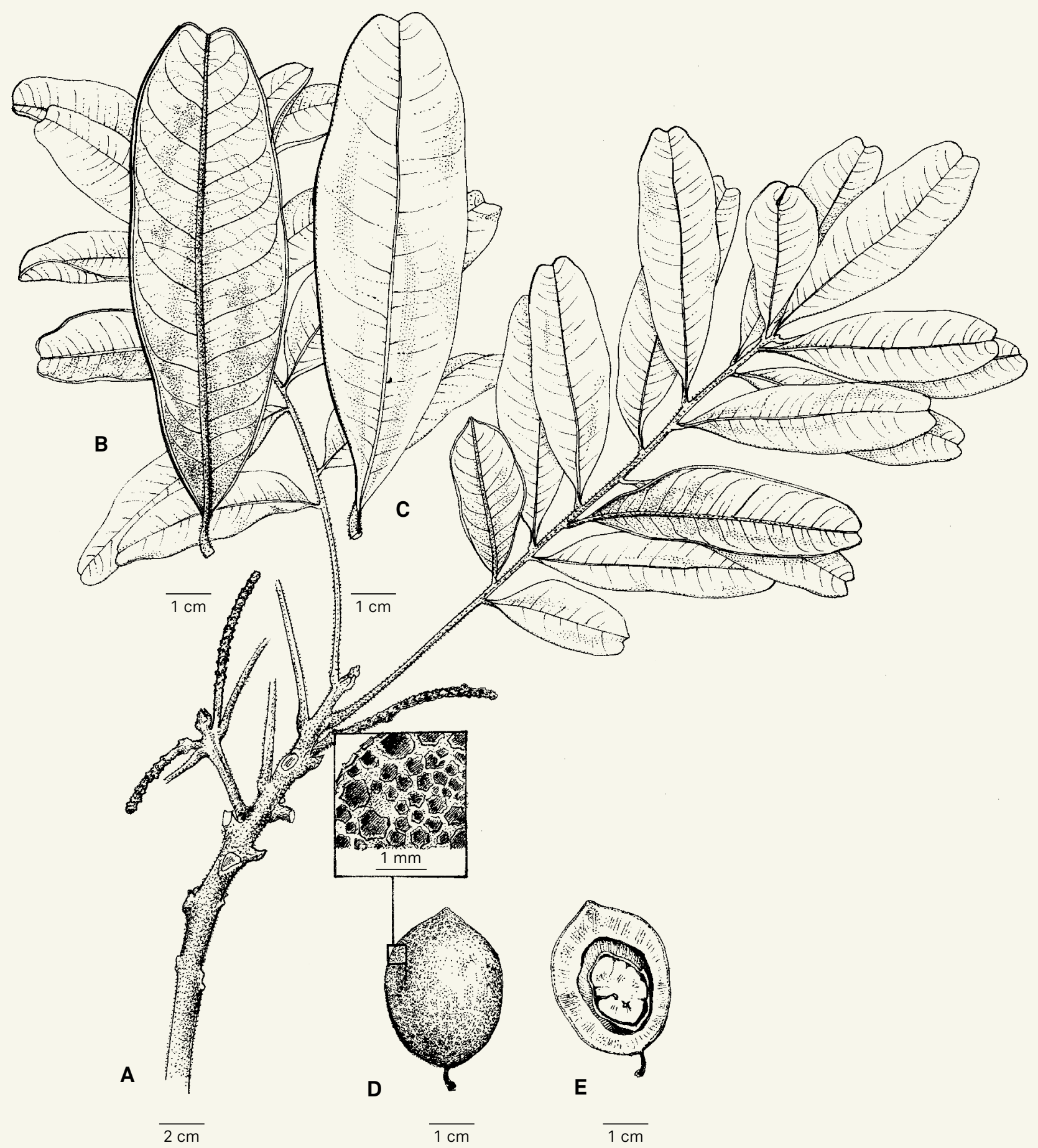

Fig. 5. - Beguea australis G.E. Schatz, Gereau \& Lowry. A. Fruiting branch; B. Leaflet (lower surface); C. Leaflet (upper surface); D. Fruit (with close-up of surface); E. Section of fruit. [Randriamampionona 633, MO] [Drawing: R.L. Andriamiarisoa] 
Notes. - Beguea australis is known from only two collections made in humid forest at Andohahela National Park (Fig. 4). It can be easily recognized from all other species of Beguea by its large leaves with 12-30 leaflets whose apex is usually deeply emarginate, and its large woody fruits with a wall 3-4.7 $\mathrm{mm}$ thick (Fig. 5).

Paratypi. - Madagascar. Prov. Toliara: Anosy Region, RNI 11, Andohahela, Parcelle 1, Isaka Ivondro, 2440'S 4652'E, 100-500 m, 12-23.VI.1993, fr., Randriamampionona 454 (BM, G, K, MO, NY, P, TAN, US).

4. Beguea betamponensis G.E. Schatz, Gereau \& Lowry, spec. nova (Fig. 6).

Typus: Madagascar. Prov. Toamasina: Atsinanana Region, RNI de Betampona, piste principale, $17^{\circ} 55^{\prime} \mathrm{S}$ 49¹3'E, 300-400 m, 30.XI.1994, fl., Andrianarisata et al. 246 (holo-: MO-6704232!; iso-: P [P06168886]! TAN!).

Haec species a congeneris indumento stellato-fasciculato, foliolis coriaceis marginibus valde revolutis apice rotundatis atque inflorescentia raro ramosa distinguitur.

Tree c. $13 \mathrm{~m}$ tall; young stems with dense golden stellate-fasciculate indument, glabrescent. Petioles 2.8$5.4 \mathrm{~cm}$, with sparse strongly appressed golden stellate indument. Leaves with 3-8 subopposite to alternate leaflets; rachis $2.7-10 \mathrm{~cm}$, keeled above, glaucous with sparse, strongly appressed golden stellate indument; petiolule 1-5 mm or leaflets sometimes subsessile, with sparse golden stellate-fasciculate indument, glabrescent; leaflet blade $3.2-10 \times 1.5-3.5 \mathrm{~cm}$, oblanceolate to occasionally elliptic, very coriaceous, flat in pressed material, glabrous and glossy above, glabrous and dull below, base asymmetrical, acute to cuneate, margins strongly revolute with up to $3 \mathrm{~mm}$ rolled under in dried material, apex rounded, midvein slightly raised above, distinctly raised below, slightly glaucous, with sparse appressed golden stellate indument, secondary veins $12-16$ per side, flat to slightly impressed above, raised below, tertiary venation slightly raised and evident above. Inflorescence axis 6$19 \mathrm{~cm}$, unbranched, or bifurcating towards the apex, reddish, essentially glabrous with very sparse golden stellate-fasciculate indument; bracts c. $0.3 \mathrm{~mm}$, triangular; pedicels $2.5-3.5 \mathrm{~mm}, 0.3-0.4 \mathrm{~mm}$ in diam., densely golden strigulose and also with appressed golden stellate-fasciculate trichomes. Male flowers with a cupulate, 5- or 6-lobed calyx, the lobes c. $0.5 \times 0.5 \mathrm{~mm}$, triangular, acute, glabrous outside, densely golden setaceous inside; stamens 8 , filaments c. $4.5 \mathrm{~mm}$, glabrous except for sparse trichomes toward the base, anthers c. $1.1 \times 0.4 \mathrm{~mm}$, ellipsoid; disc and pistillode densely golden setaceous, the trichomes to $0.5 \mathrm{~mm}$. Female flowers not seen. Fruit not seen.
Conservation status. - Although Beguea betamponensis is known only from the fairly well-protected Betampona Strict Nature Reserve (Fig. 4), its current status with regard to population size and reproduction, and also the potential negative impact from invasive strawberry guava (Psidium cattleyanum Sabine), is unknown. With a restricted $\mathrm{AOO}$ and the potential threat from such an aggressive invasive, which could rapidly push the species to "Critically Endangered" or "Extinct" status, B. betamponensis is here assigned the category of "Vulnerable" [VU D2] using the IUCN Red List Criteria (IUCN, 2012).

Notes. - Beguea betamponensis is known only from the type collection in humid forest at the Betampona Strict Nature Reserve (Fig. 7), where it is sympatric with $B$. apetala. It can be easily distinguished from $B$. galokensis, with which it shares an indument of tufts of very short golden stellate-fasciculate trichomes, by its very coriaceous leaflets with strongly revolute margins, rounded apex lacking a mucro, and impressed secondary veins (vs subcoriaceous leaflets with slightly revolute margins, acute to acuminate apex with a distinct mucro, and flat to slightly raised secondary veins) and its occasionally branched inflorescences (vs unbranched inflorescences) (Fig. 6).

\section{Beguea birkinshawii G.E. Schatz, Gereau \& Lowry, spec. nova (Fig. 7).}

Typus: Madagascar. Prov. Antsiranana: DIANA Region, RNI 6, Lokobe, S side of reserve, $5 \mathrm{~km} \mathrm{SE}$ of Hell Ville, Nossi Be, 13²5’S 48¹8'E, 200 m, 31.VIII.1992, fl., Birkinshaw 159 (holo-: MO-04958842! ; iso- : G [G00341316]!, P [P06168881]!,TAN!).

Haec species a congeneris caulibus petiolis folioli costa et inflorescentiae axe indumento cacao-brunneo tomentulosis atque pedicellis gracilibus distinguitur.

Tree 8-20 m tall, bole to $35 \mathrm{~cm}$ in diam; stems densely light chocolate brown tomentulose. Petioles $4.3-7.3 \mathrm{~cm}$, channeled, densely light chocolate brown tomentulose. Leaves with 10-14 subopposite to alternate leaflets; rachis $8.5-14 \mathrm{~cm}$, not keeled, densely light chocolate brown tomentulose; petiolule 2-5 mm, densely light chocolate brown tomentulose; leaflet blade 3.5-10.1 × 1.3-2.5 cm, lanceolate to ovate, chartaceous, flat in pressed material, glabrous and glossy and sometimes verrucose above, glabrous and somewhat glaucous below, base asymmetrical, cuneate to attenuate, margins flat, apex acuminate, the acumen rounded to irregularly retuse, midvein flat to slightly raised towards the base above, initially light chocolate-ferruginous tomentulose, glabrescent, distinctly raised below, persistently light chocolate-ferruginous tomentulose, secondary veins $12-16$ per side, flat to slightly impressed above, 


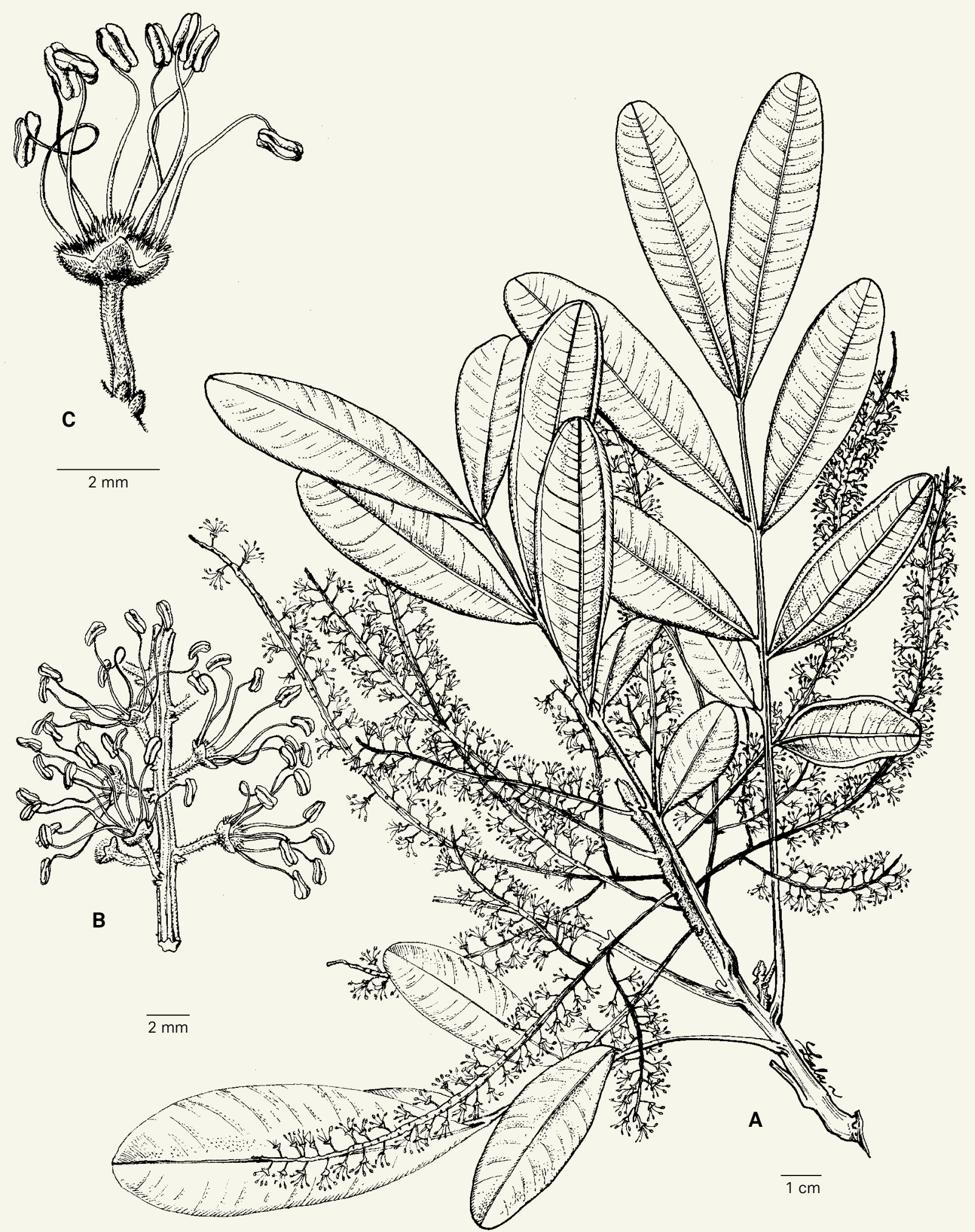

Fig. 6. - Beguea betamponensis G.E. Schatz, Gereau \& Lowry. A. Flowering branch; B. Portion of inflorescence axis; C. Detail of flower at anthesis. [Andrianarisata et al. 246, MO] [Drawing: R.L. Andriamiarisoa] 


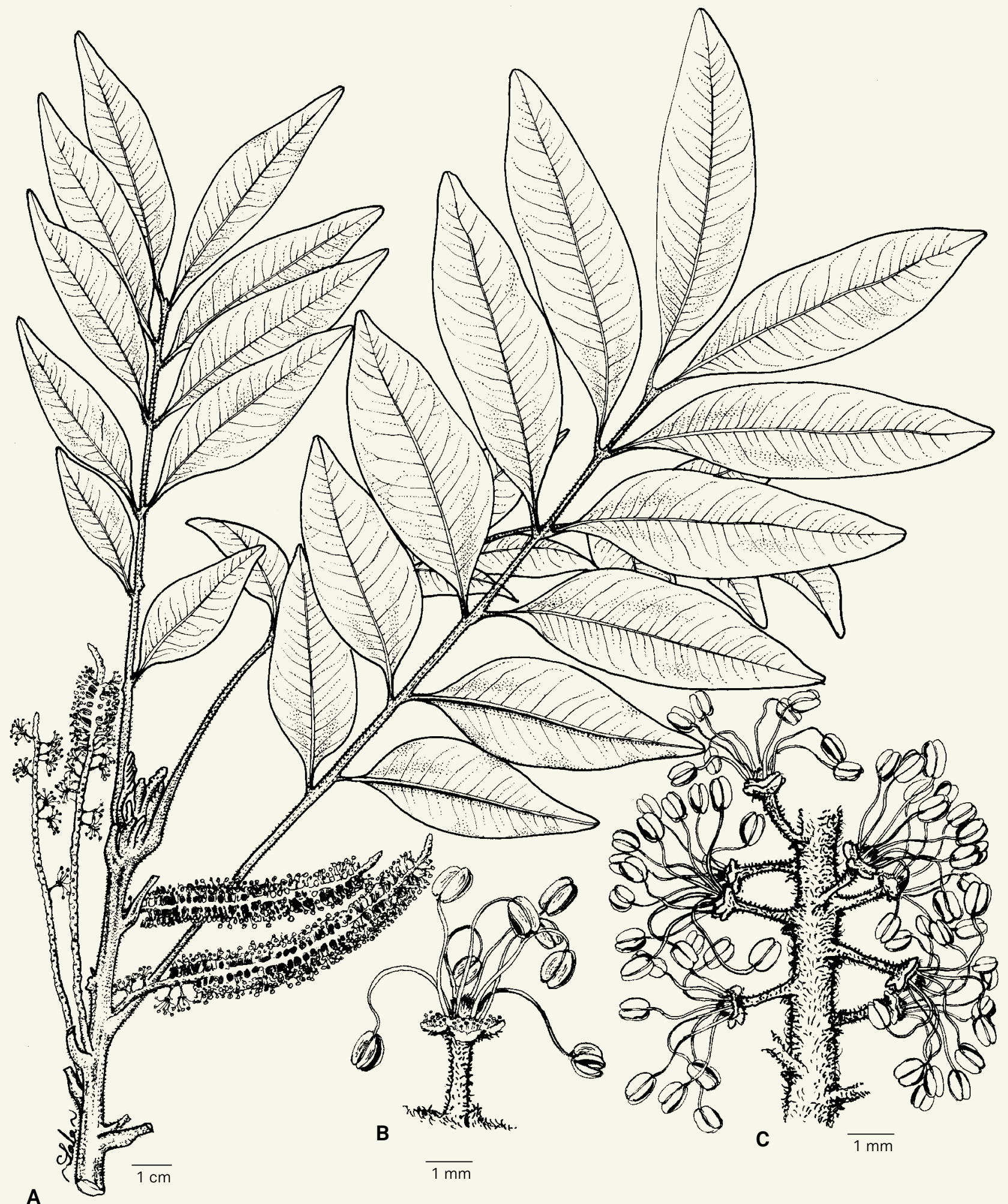

Fig. 7. - Beguea birkinshawii G.E. Schatz, Gereau \& Lowry. A. Flowering branch; B. Detail of flower at anthesis; C. Portion of inflorescence axis. [Birkinshaw 159, MO] [Drawing: R.L. Andriamiarisoa] 
raised below, tertiary venation reticulate, slightly raised and evident above. Inflorescence axis $4-18.5 \mathrm{~cm}$ long, c. $1.5 \mathrm{~mm}$ in diam., unbranched, densely light reddish chocolate tomentose, bracts minute, $<0.1 \mathrm{~mm}$; pedicels $2.5-3.5 \mathrm{~mm}, 0.2-0.5 \mathrm{~mm}$ in diam., sparsely light chocolate tomentulose. Male flowers with a cupulate, 5-lobed calyx, the lobes c. $0.5 \times 0.5 \mathrm{~mm}$, triangular, sparsely light chocolate tomentulose; stamens 8 , filaments c. $4.5 \mathrm{~mm}$, glabrous, anthers c. $1 \times 0.5 \mathrm{~mm}$, ellipsoid; disc c. $1.2 \mathrm{~mm}$ in diam., sparsely whitish granular-farinose; pistillode c. $0.5 \mathrm{~mm}$, conical, densely golden hirsute. Female flowers not seen. Infructescence $12-16 \mathrm{~cm}$, c. $1.5 \mathrm{~mm}$ in diam., densely light reddish chocolate tomentose; pedicels 4-5 mm, 0.9-1 mm in diam. in fruit, glabrous. Fruit ellipsoid to obovoid, $1.7-1.8 \mathrm{~cm}, \mathrm{c.} 1.2 \mathrm{~cm}$ in diam., glabrous to sparsely whitish granular farinose at the base and apex, base obtuse, apex rounded, apiculate, the apiculum c. $0.7 \mathrm{~mm}$, fruit wall c. $0.8 \mathrm{~mm}$ thick; seed flattened ellipsoid, c. $10 \times 7 \times 3.5 \mathrm{~mm}$.

Etymology. - The epithet birkinshawii honors Chris Birkinshaw, who collected the type material while conducting his thesis work in the Lokobe reserve, and who has been an inspirational leader of plant conservation efforts in Madagascar.

Conservation status. - Despite the very restricted AOO within the well-protected Lokobe Special Reserve (Fig. 4), there appear to be no current threats, and thus Beguea birkinshawii is assigned a status of "Least Concern" [LC] using the IUCN Red List Criteria (IUCN, 2012), with the caution that this status is highly dependent on continued effective protection.

Notes. - Beguea birkinshawii is known only from subhumid forest in the Lokobe Special Reserve on the island of Nossi Be (Fig. 4). It can be distinguished from B. turkii, the species most similar morphologically, by its slender pedicels (0.2-0.5 $\mathrm{mm}$ in diam. in flower, $0.9-1 \mathrm{~mm}$ in diam. in fruit vs $0.7-0.9 \mathrm{~mm}$ in diam. in flower, $1.3-1.5 \mathrm{~mm}$ in diam. in fruit), smaller sepals (c. $0.5 \mathrm{~mm}$ vs c. $1.5 \mathrm{~mm}$ long), and smaller ellipsoid to obovoid fruit (1.7-1.8 cm long, c. $1.2 \mathrm{~cm}$ in diam vs globose fruit $2.3-2.8 \mathrm{~cm}$ in diam) (Fig. 7).

Paratypi. - Madagascar. Prov. Antsiranana: DIANA Region, Sambirano, forêt du Lokobe (Nosy Be), [1325'S 48¹8'E], 2.XI.1954, fr., Service Forestier 11412 (P); ibid. loc., 2.XI.1954, fl., Service Forestier 11415 (P).
6. Beguea borealis G.E. Schatz \& Lowry, spec. nova (Fig. 8). Typus: Madagascar. Prov. Antsiranana : DIANA Region, Montagne des Français, forêt d'Ampitiliantsambo, à $3 \mathrm{~h}$. de marche à pied, à l'E d'Andranomanitra, $12^{\circ} 23^{\prime} 13^{\prime \prime S} 49^{\circ} 23^{\prime} 04^{\prime \prime E}, 205$ m, 14.I.2005, fl., Randrianaivo et al. 1163 (holo-: P [P04765740]!; iso-: MO, TAN!).

Haec species a congeneris caulibus petiolis petiolulisque indumento aureo dense tomentulosis atque foliolis conduplicat is 4 ad 6 venis secundariis in quoque latere 7 ad 10 distinguitur.

Tree c. $12 \mathrm{~m}$ tall, bole c. $15 \mathrm{~cm}$ in diam.; stems densely golden tomentulose, glabrescent. Petioles $1.7-3.6 \mathrm{~cm}$, densely golden tomentulose. Leaves with 4-6 subopposite to opposite leaflets; rachis $0.2-2.1 \mathrm{~cm}$, not keeled, densely golden tomentulose; petiolule 2-4 mm, light gray-tan tomentulose; leaflet blade 3.3-4.6 × 1.6-2.4 cm, elliptic (occasionally very slightly ovate or obovate), subcoriaceous, nearly always conduplicate and folded along the midvein in pressed material, glabrous and glossy above, glabrous below except very sparsely tomentulose at the base, base symmetrical, cuneate to acute, margins flat, minutely thickened but not revolute, apex acuminate, the acumen rounded, midvein flat above, sparsely tomentulose, raised below, sparsely tomentulose towards the base, secondary veins $7-10$ per side, slightly raised above and below, tertiary venation raised on both surfaces. Inflorescence axis $1.5-9.7 \mathrm{~cm}$ long, c. $1 \mathrm{~mm}$ in diam. at base, unbranched, sparsely tan sericeous; bracts c. $0.2 \mathrm{~mm}$, triangular, adaxially concave; pedicels usually paired on a common peduncle to $1 \mathrm{~mm}$, sometimes solitary and epedunculate, $0.5-1.5 \mathrm{~mm}$, moderately to densely tan sericeous. Male flowers with a cupulate, 5- to 7-lobed calyx, the lobes $0.2-0.3 \times 0.3-0.6 \mathrm{~mm}$, broadly triangular, sparsely tan sericeous outside; disc glabrous to sparsely white granular-farinose; stamens 8 (or 9), filaments c. $2 \mathrm{~mm}$, with sparse spreading trichomes along basal third, anthers 0.7-0.8 $\times$ 0.3-0.4 mm, oblong; pistillode $0.2-0.3 \mathrm{~mm}$ high, $0.2-0.3 \mathrm{~mm}$ in diam., hemispherical, covered with short appressed trichomes. Female flowers not seen. Fruit not seen.

Etymology. - The epithet borealis refers to the northernmost occurrence of the genus Beguea in Madagascar.

\section{Vernacular name. - "Gavoala".}

Conservation status. - While Beguea borealis occurs within the recently decreed Montagne des Français (Ambohitr'Antsingy) protected area, it was collected adjacent to a clearing used as pasture and subject to potential burning, threats that may continue despite the new protected status. Therefore, with a restricted $\mathrm{AOO}$ and plausible threats that could rapidly push the species to Critically Endangered or Extinct status, $B$. borealis warrants a preliminary assessment of "Vulnerable" [VU D2] using the IUCN Red List Criteria (IUCN, 2012). 


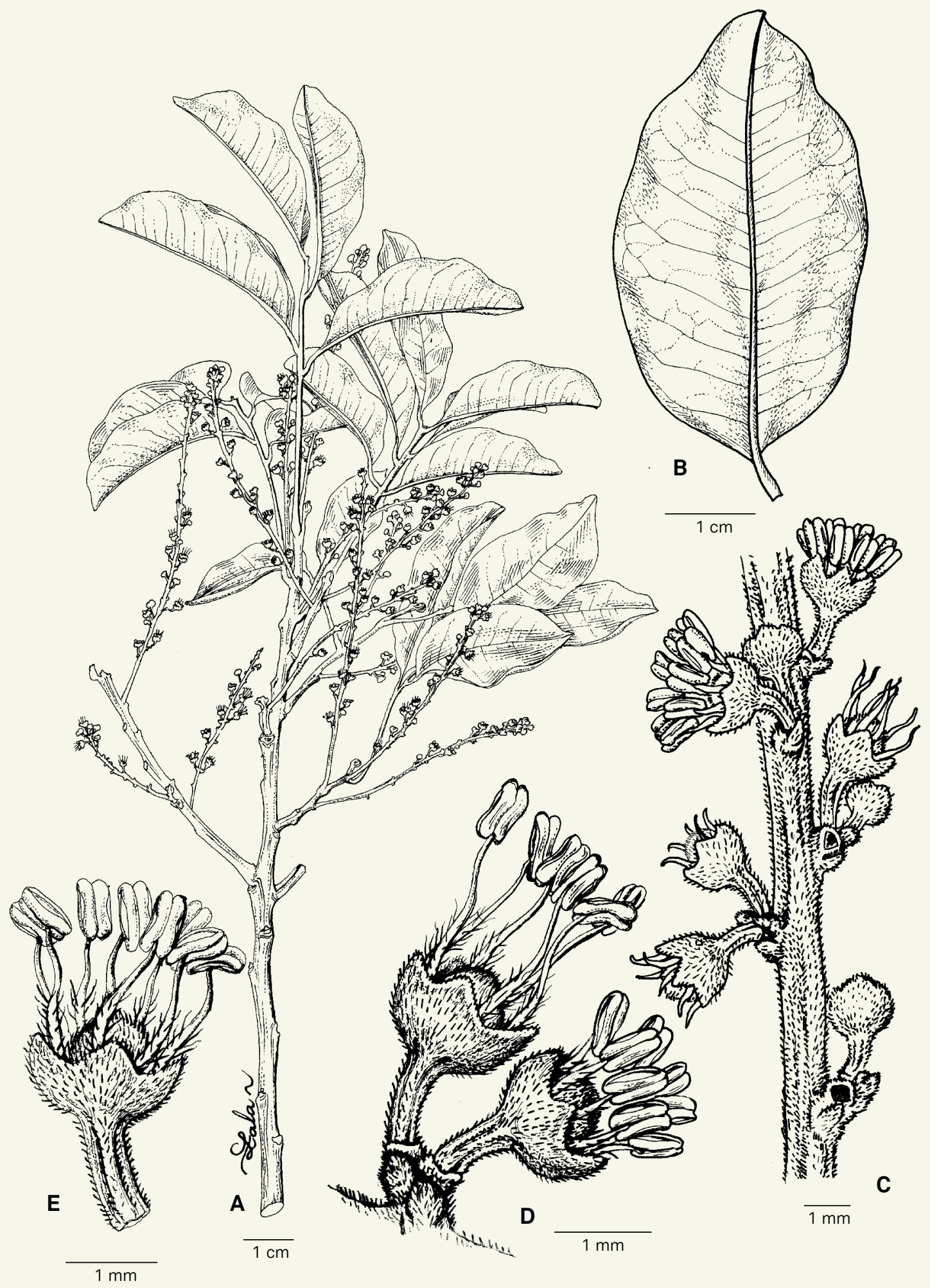

Fig. 8. - Beguea borealis G.E. Schatz \& Lowry. A. Flowering branch; B. Leaflet (lower surface); C. Portion of inflorescence axis; D. Two flowers (one with filaments only partially expanded); $\mathbf{E}$. Detail of flower at anthesis. [Randrianaivo et al. 1163, P]. [Drawing: R.L. Andriamiarisoa] 
Notes. - Beguea borealis is known only from the type specimen from the Forêt d'Ampitiliantsambo within the Montagne des Français massif (Fig. 4). It can be distinguished from $B$. apetala, with which it shares conduplicate leaflets that are usually folded along the midvein in pressed material, by its leaflets with a symmetrical base, the margins flat and minutely thickened but not revolute (vs leaflets with a distinctly asymmetrical base and strongly revolute margins) (Fig. 8).

\section{Beguea galokensis G.E. Schatz \& Lowry, spec. nova (Fig. 9).}

Typus: Madagascar. Prov. Antsiranana: DIANA Region, Ambilobe, Beramanja, Anketrabe Belinta, forêt de Galoko, riv. Andohaniamabahatra, $13^{\circ} 35^{\prime} 17^{\prime \prime} \mathrm{S}$ 4842'43”E, 336 m, 5.X.2013, fl., Manjato et al. 454 (holo-: MO-6701389! ; iso- : G, K, P [P01060305]!, TAN!).

Haec species a congeneris foliorum petiolis rhachidibus petiolulisque trichomatum aureorum perbrevium stellatofasciculatorum caespitibus dense indutis atque foliolorum lamina adaxialiter dense punctata apice breviter mucronata distinguitur.

Tree c. $7 \mathrm{~m}$ tall; stems densely light brown tomentulose, glabrescent. Petioles $3.5-7.5 \mathrm{~cm}$, densely covered with tufts of very short, golden stellate-fasciculate trichomes. Leaves with 4-14 alternate to sub-opposite leaflets; rachis $0.8-16.6 \mathrm{~cm}$, keeled above, densely covered with tufts of very short golden stellate-fasciculate trichomes; petiolule 3-5 mm, densely covered with tufts of very short golden stellate-fasciculate trichomes; leaflet blade 3.7-10.6 × 1.3-2.3 cm, narrowly elliptic, subcoriaceous, flat in pressed material, glabrous and glossy and densely punctate above, glabrous below, base markedly asymmetrical, attenuate to cuneate to rarely acute, margins slightly revolute, apex acute to acuminate, the acumen rounded and often with a short mucro, midvein raised above and below, sparsely covered with tufts of very short golden stellatefasciculate trichomes on both sides, secondary veins $13-17$ per side, flat to slightly raised above and below, tertiary venation flat on both surfaces. Inflorescence axis 4.3-17 cm long, c. $1 \mathrm{~mm}$ in diam., unbranched, moderately covered with tufts of very short golden stellate-fasciculate trichomes; bracts c. $0.5 \mathrm{~mm}$, triangular, flat, caducous; pedicels usually paired on a common peduncle to $0.5 \mathrm{~mm}$, sometimes solitary and epedunculate, 2-4 mm, moderately to densely covered with tufts of very short golden stellate-fasciculate trichomes. Male flowers with a cupulate, 5-lobed calyx, the lobes broadly triangular, 0.3-0.6 $\times 0.2-0.5 \mathrm{~mm}$, moderately covered with tufts of very short golden stellate-fasciculate trichomes outside; disc obscured by the pistillode; stamens 7-9, filaments c. $2.8 \mathrm{~mm}$, with sparse spreading trichomes along basal half, anthers 1.0-1.1 × 0.6$0.8 \mathrm{~mm}$, oblong; pistillode $0.2-0.3 \mathrm{~mm}$ high, $0.2-0.3 \mathrm{~mm}$ in diam., hemispherical to depressed hemispherical, disc 0.3$0.5 \mathrm{~mm}$ high, $1 \mathrm{~mm}$ in diam., densely covered with stiff erect golden trichomes to $0.4 \mathrm{~mm}$ long. Female flowers not seen. Fruit not seen.

Conservation status. - While Beguea galokensis occurs within the recently decreed Galoko-Kalobinono protected area (Fig. 3 ), it was collected adjacent to a clearing used as pasture and subject to potential burning, threats that may continue despite the new protected status. Therefore, with a restricted AOO and plausible threats that could rapidly push the species to Critically Endangered or Extinct status, B. galokensis warrants a preliminary assessment of "Vulnerable" [VU D2] using the IUCN Red List Criteria (IUCN, 2012).

Notes. - Beguea galokensis is known only from the type specimen from the Forêt de Galoko, a site of high local endemism from which a number of new species have been recently described, including Canarium galokense Daly, Raharim. \& Federman (DALY et al., 2015), Micronychia benono Randrian. \& Lowry (Randrianasolo \& Lowry, 2009) and Polyscias wohlhauseri Lowry \& Callm. (CALlmander et al., 2009) (Fig. 3). It can be easily distinguished from B. betamponensis, with which it shares an indument of tufts of very short golden stellate-fasciculate trichomes, by its subcoriaceous leaflets with slightly revolute margins, acute to acuminate apex with a distinct mucro, and flat to slightly raised secondary veins (vs very coriaceous leaflets with strongly revolute margins, rounded apex lacking a mucro, and impressed secondary veins) and its unbranched inflorescence (vs occasionally branched inflorescence) (Fig. 9).

\section{Beguea tsaratananensis G.E. Schatz, Gereau \& Lowry, spec.} nova (Fig. 10).

Typus : Madagascar. Prov. Antsiranana : DIANA Region, Tsaratanana Massif, southern slopes, 14 03'26”S 4855'29”'E, 1622 m, 2.XI.2000, fl., Antilabimena 631 (holo-: MO-6641488! ; iso-: BM, G!, K!, L!, P [P06168857]!, TAN!).

Haec species a congeneris caulibus petiolis et folii rbachide dense breviterque aureo-sericeis (petiolis rhachideque deinde glabrescentibus), foliolis in sicco complanatis marginibus non revolutis costa abaxialiter parce sericeis apice acutis acuminatisve atque sepalis glabris distinguitur.

Tree to $14 \mathrm{~m}$ tall, bole c. $19 \mathrm{~cm}$ in diam.; stems densely golden short sericeous. Petioles $2.3-6.6 \mathrm{~cm}$, densely golden short sericeous, glabrescent. Leaves trifoliolate or with 4-11 subopposite to alternate leaflets; rachis $2.2-11.7 \mathrm{~cm}$, not keeled, initially densely short golden sericeous, glabrescent; petiolule 


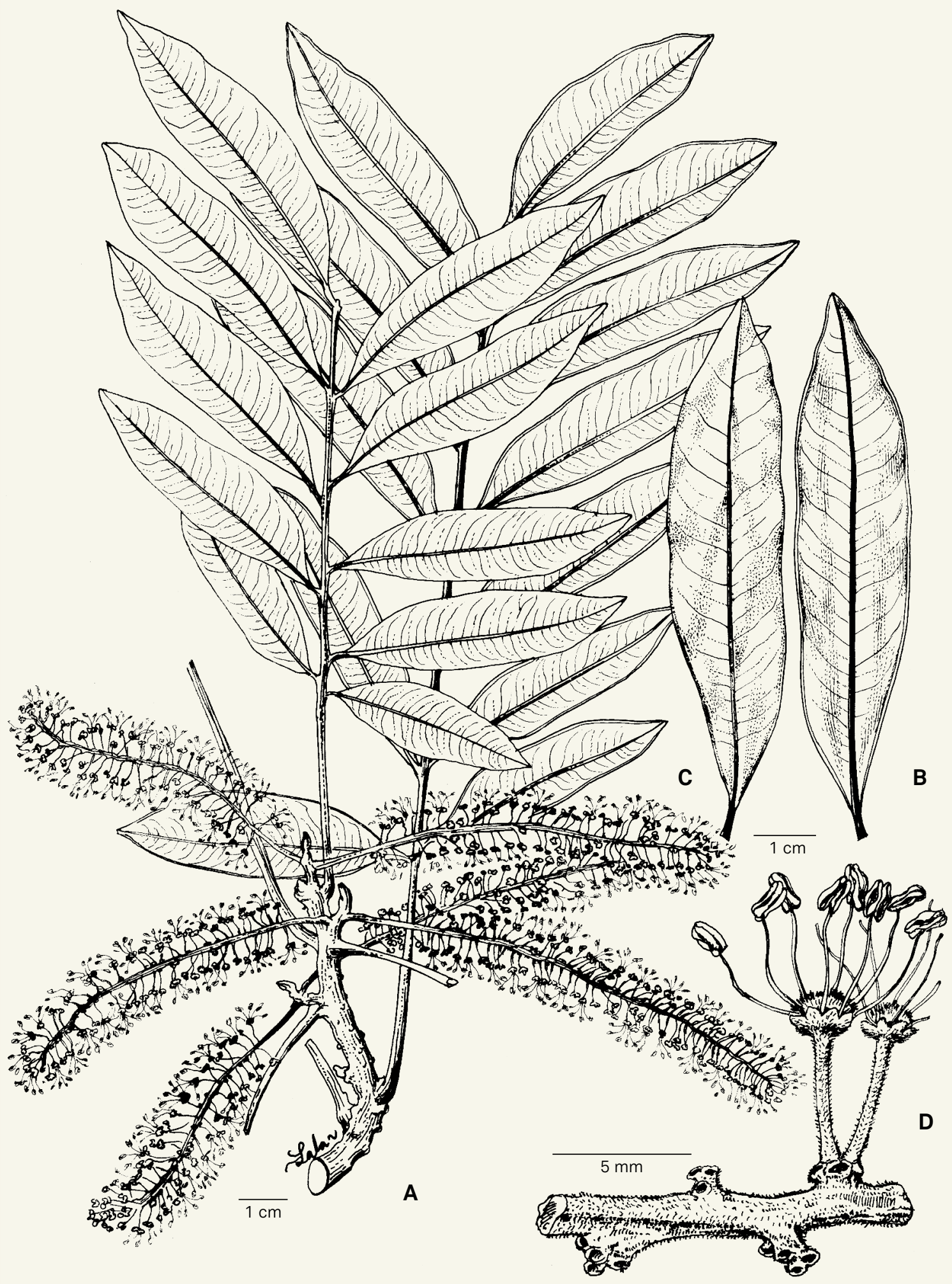

Fig. 9. - Beguea galokensis G.E. Schatz \& Lowry. A. Flowering branch; B. Leaflet (lower surface); C. Leaflet (upper surface); D. Portion of inflorescence axis with two flowers.

[Manjato et al. 454, P] [Drawing: R.L. Andriamiarisoa] 


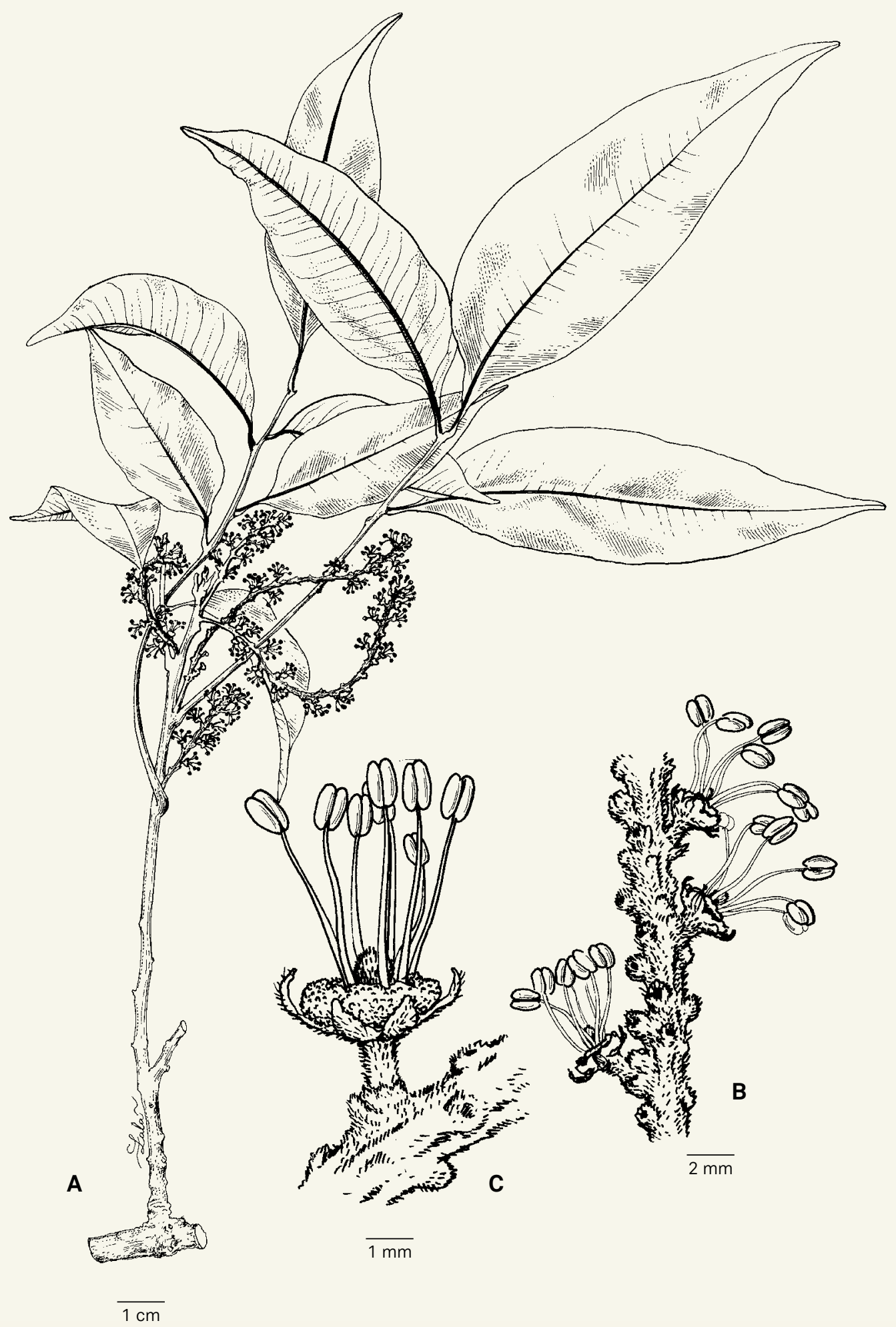

Fig. 10. - Beguea tsaratananensis G.E. Schatz, Gereau \& Lowry. A. Flowering branch; B. Portion of inflorescence axis; C. Detail of flower at anthesis. [Antilahimena 631, MO] [Drawing: R.L. Andriamiarisoa] 
2-9 mm, sparsely short golden sericeous, glabrescent; leaflet blade $3.8-12.5 \times 1.7-3.9 \mathrm{~cm}$, ovate to lanceolate, chartaceous, flat in pressed material, glabrous and slightly glossy and somewhat verrucose above, glabrous and dull below, base asymmetrical, cuneate to attenuate and decurrent along petiolule, margins flat, apex acute to acuminate, midvein raised and knife-like above, glabrous, raised below, sparsely short sericeous, secondary veins $12-17$ per side, flat to slightly raised above, flat below, tertiary venation slightly raised above, flat below. Inflorescence axis 3-12 cm long, $0.9-1 \mathrm{~mm}$ in diam., unbranched, densely golden ferruginous strigulose; bracts minute, c. $0.2 \mathrm{~mm}$, narrowly triangular; pedicels $0.5-1.5 \mathrm{~mm}$, c. $0.2 \mathrm{~mm}$ in diam., densely golden ferruginous strigulose. Male flowers with a cupulate, 5- or 6-lobed calyx, the lobes c. $1.0 \times 0.5 \mathrm{~mm}$, triangular, glabrous; stamens usually 7 (rarely 6 or 8 ), filaments $1.8-4.5 \mathrm{~mm}$, glabrous, anthers c. $1 \times$ $0.5 \mathrm{~mm}$, ellipsoid; disc $1.6 \mathrm{~mm}$ in diam., densely white granular-farinose; pistillode $0.6 \mathrm{~mm}$ tall, conical, densely ferruginous setaceous. Female flowers not seen. Fruit not seen.

Conservation status. - Despite the very restricted AOO based upon two localities within the well-protected Tsaratanana Strict Nature Reserve (Fig. 4), there appear to be no current threats, and thus $B$. tsaratananensis is assigned a status of "Least Concern" [LC] using the IUCN Red List criteria (IUCN, 2012), with the caution that this status is highly dependent on continued effective protection.

Notes. - Beguea tsaratananensis is known only from two collections from the Tsaratanana massif (Fig. 4). It can be recognized from other members of the genus by the short, dense, golden sericeous indument of the stems, young petioles and leaf rachises, the non-folded leaflets with flat margins and the midrib sparsely sericeous beneath, and the glabrous sepals of the male flowers. It can be distinguished from the morphologically similar B. vulgaris by its leaflets with flat (vs revolute) margins and glabrous (vs puberulous) sepals (Fig. 11).

Paratypi. - Madagascar. Prov. Antsiranana: DIANA Region, Tsaratanana RNI, Fokontany Beangona, à $8 \mathrm{~km} \mathrm{E}$ de Beangona, Antsahamanara, $14^{\circ} 02^{\prime} 50$ ”S 48 47'09”E, 1408 m, 29.XI.2000, fl., Razakamalala, Ratovoson E Antonjara 32 (G, K, L, MO, P, TAN).
9. Beguea turkii G.E. Schatz, Gereau \& Lowry, spec. nova (Fig. 2C, 11).

Typus : Madagascar. Prov. Fianarantsoa: VatovavyFitovinany Region, Ranomafana National Park, parcelle 3, S of National Road 25 at $7 \mathrm{~km} \mathrm{~W}$ of Ranomafana, Vatoharanana trail system, $21^{\circ} 17^{\prime} \mathrm{S} 47^{\circ} 26^{\prime} \mathrm{E}, 1100-1250 \mathrm{~m}$, 3.XII.1992, fl., Turk E Solo 192 (holo-: MO-05035874! ; iso- : P [P00214653]!, TAN!).

Haec species a congeneris caulibus petiolis folii rhachide petiolulis folioli costa inflorescentiae axe et pedicellis indumento ferrugineo dense tomentosis atque pedicellis crassis distinguiter.

Trees 10-17 m tall, bole to $17 \mathrm{~cm}$ diam.; stems densely ferruginous tomentose, glabrescent. Petioles $2.3-5.5 \mathrm{~cm}$, densely ferruginous tomentose. Leaves with 7-16 subopposite to alternate leaflets; rachis $2.8-12.2 \mathrm{~cm}$, not keeled, densely ferruginous tomentose; petiolule 1-3 mm, swollen, densely ferruginous tomentose; leaflet blade $1.8-8.1 \times 0.8-2.3 \mathrm{~cm}$, lanceolate to narrowly oblong, chartaceous to subcoriaceous, flat in pressed material, glabrous above, initially ferruginous tomentose below, glabrescent, base markedly asymmetrical, margins slightly revolute, apex acuminate, the acumen rounded to sometimes slightly retuse, midvein raised above, initially densely ferruginous tomentose, glabrescent, raised below, persistently densely ferruginous tomentose, secondary veins 14-21 per side, ascending at an angle of $25^{\circ}$ from the midvein, slightly raised above and below, tertiary veins finely reticulate, slightly raised above and below. Inflorescence axis $8-15 \mathrm{~cm}$ long, $1.5-2.5 \mathrm{~mm}$ in diam., unbranched, densely ferruginous tomentose; bracts $0.7-1 \mathrm{~mm}$, triangular, adaxially concave; pedicels 3-4 mm, 0.7-0.9 mm in diam., densely ferruginous tomentose. Male flowers with a cupulate, 5- or 6-lobed calyx, the lobes c. $1.5 \times 0.5 \mathrm{~mm}$, erect and curved inwards slightly, densely ferruginous tomentose outside, glabrous inside; disc c. $1.5 \mathrm{~mm}$ in diam., drying dark, glabrous to sparsely golden granular-farinose; stamens 6-8, filaments 3-4 mm, glabrous, anthers c. $1 \times 0.5 \mathrm{~mm}$, ellipsoid. Female flowers not seen. Infructescence $7.5-8.2 \mathrm{~cm}$, c. $2 \mathrm{~mm}$ in diam., densely ferruginous tomentose; pedicels $1.3-1.5 \mathrm{~mm}$ in diam. in fruit, densely ferruginous tomentose. Fruit spheroid, glabrous, $2.3-2.8 \mathrm{~cm}$ in diam., abruptly apiculate, the apiculum c. $1 \mathrm{~mm}$; the fruit wall c. $1 \mathrm{~mm}$ thick; seed discoid , $12-14 \mathrm{~mm}$ in diam., c. $0.5 \mathrm{~cm}$ thick.

Etymology. - The epithet turkii honors Dan Turk, who has significantly advanced our knowledge of the trees of Ranomafana National Park, and who continues to promote the cultivation of indigenous Malagasy trees.

Conservation status. - Beguea turkii has a restricted range size (Fig. 4), with an EOO of $8,550 \mathrm{~km}^{2}$ and an $\mathrm{AOO}$ of less than $500 \mathrm{~km}^{2}$. While there may be no current threats at its locations in Andohahela and Ranomafana National Parks, 


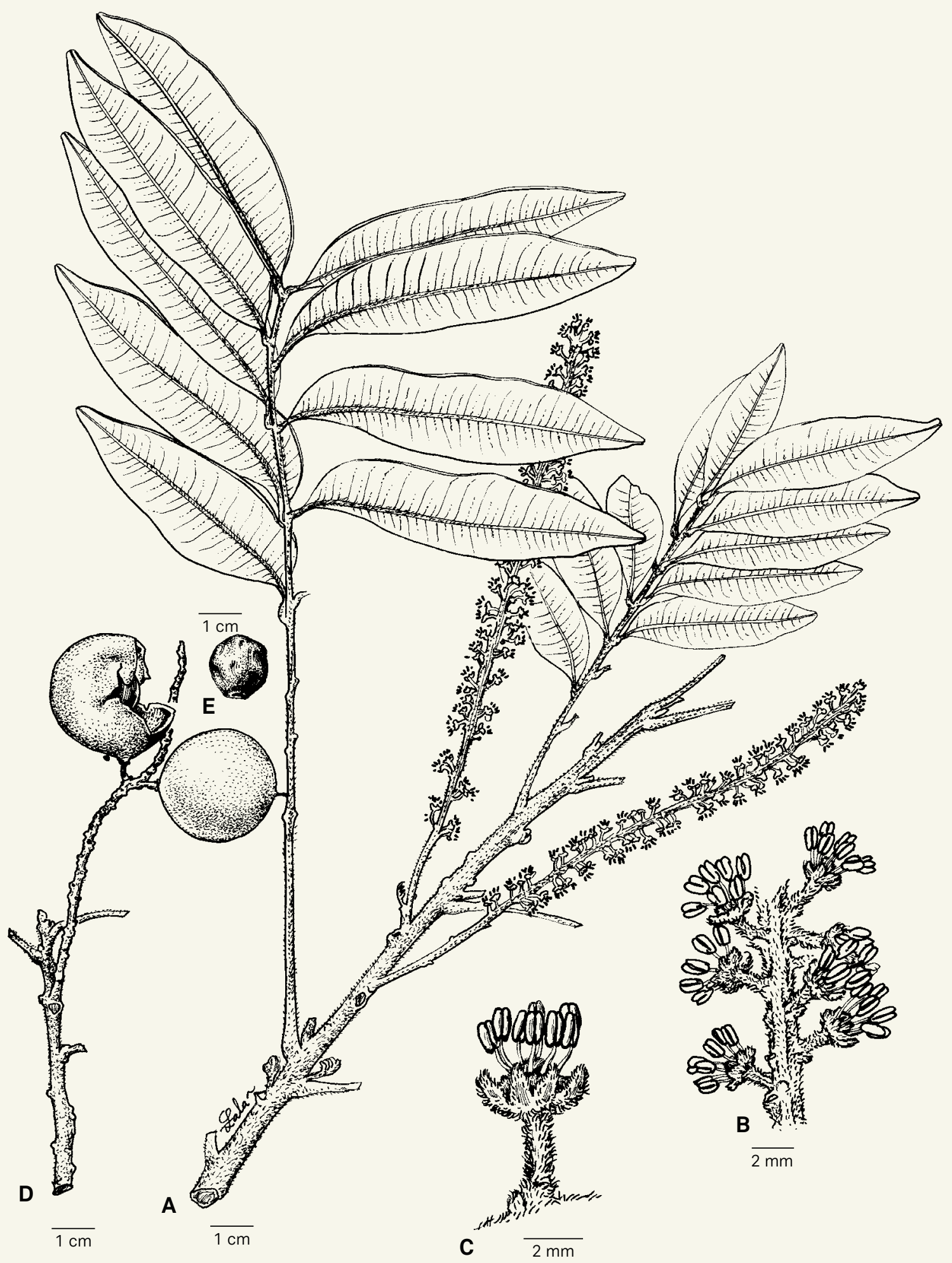

Fig. 11. - Beguea turkii G.E. Schatz, Gereau \& Lowry. A. Flowering branch; B. Portion of inflorescence axis; C. Detail of flower at anthesis; D. Infructescence axis with fruits; E. Seed.

[A-C: Turk \& Solo 192, MO; D: Rakotomalaza 492, MO] [Drawing: R.L. Andriamiarisoa] 
continuing decline in the quality of the habitat from forest exploitation and clearing can be projected at the northern SAVA location southwest of the village of Morafeno along the boundary of the "Corridor forestier Marojejy-Anjanaharibe Sud-Tsaratanana Nord". Therefore, $B$. turkii is assigned a preliminary status of "Endangered" [EN B2ab(iii)] using the IUCN Red List Criteria (IUCN, 2012).

Notes. - Beguea turkii is known from three widely dispersed locations in mid-elevation subhumid forest (Fig. 4). It can be distinguished from B. birkinshawii, the species most similar morphologically, by its stout pedicels $(0.7-0.9 \mathrm{~mm}$ in diam. in flower, $1.3-1.5 \mathrm{~mm}$ in diam. in fruit vs $0.2-0.5 \mathrm{~mm}$ in diam. in flower, $0.9-1 \mathrm{~mm}$ in diam. in fruit vs), larger sepals (c. $1.5 \mathrm{~mm}$ vs c. $0.5 \mathrm{~mm}$ long), and larger spheroid fruit (2.3$2.8 \mathrm{~cm}$ in diam vs ellipsoid to obovoid and $1.7-1.8 \mathrm{~cm}$ long, c. $1.2 \mathrm{~cm}$ in diam) (Fig. 11).

Paratypi. - Madagascar. Prov. Antsiranana : SAVA Region, forêt d'Antsahandroboka, située à env. $10 \mathrm{~km}$ au SW du village de Morafeno, sentier d'Antsahandavakanjo vers Antsahabaraoka, 1409'26"S 49²3'09”'E, 1010 m, 18.II.2007, fl., Rakotovao et al. 3648 (G, P, MO, TAN). Prov. Fianarantsoa: Vatovavy-Fitovinany Region, Ranomafana NP, parcelle 3, S of National Road 25 at $7 \mathrm{~km}$ W of Ranomafana, Valohoaka trail system, $21^{\circ} 18^{\prime} \mathrm{S} 47^{\circ} 26^{\prime} \mathrm{E}$, 1100-1250 m, 19-21.XI.1992, fl., Turk, Randrianasolo \& Solo 169 (MO, P, TAN). Prov. Toliara: Anosy Region, RNI \#11 Andohahela, Camp 3, 13.5 km NW d'Eminiminy, 2435'04”S 46 44’08”E, 1000-1400 m, 9.XI.1995, fr., Rakotomalaza 492 (MO, TAN).

\section{Beguea vulgaris G.E. Schatz, Gereau \& Lowry, spec. nova} (Fig. 2D, 12).

Typus: MADAgascar. Prov. Fianarantsoa: VatovavyFitovinanay Region, Ranomafana NP, $21^{\circ} 16^{\prime} \mathrm{S} 47^{\circ} 26^{\prime} \mathrm{E}$, 1000-1100 m, 18-31.I.1993, fl., Malcomber et al. 2058 (holo-: MO-04570269!; iso-: P [P06168859]!, TAN!).

Haec species a congeneris caulibus petiolis et folii rhachide aureo-strigulosis deinde glabrescentibus atque foliolis in sicco complanatis marginibus revolutis apice obtusis usque breviter acuminatis distinguitur.

Tree 4-25 m tall; stems densely golden strigulose, glabrescent. Petioles $2.3-6 \mathrm{~cm}$, sparsely golden strigulose, glabrescent. Leaves with 3-11 subopposite to alternate leaflets; rachis $1-14.2 \mathrm{~cm}$, not keeled, sparsely golden strigulose, glabrescent; petiolule $1-3 \mathrm{~mm}$, sparsely golden strigulose; lea flet blade $3.2-9.5 \times 0.9-4.1 \mathrm{~cm}$, elliptic, coriaceous, flat in pressed material, glabrous and glossy above, glabrous to sparsely strigulose near midvein below, dull, base asymmetrical, cuneate to attenuate and decurrent along petiolule, margins revolute, apex obtuse to acute to short acuminate, midvein slightly raised above, glabrous, raised below, sparsely strigulose, secondary veins 8-14 per side, slightly raised above, flat and indistinct or slightly raised below, tertiary venation slightly raised above and below. Inflorescence axis 3.5-12.8 cm long, 1.1-1.8 mm in diam., unbranched, densely golden hirtellous; bracts 0.6$0.8 \mathrm{~mm}$, narrowly triangular, cucullate; pedicels usually paired on a common peduncle c. $0.5 \mathrm{~mm}$, sometimes solitary and epedunculate, $2-3.8 \mathrm{~mm}$, c. $0.3 \mathrm{~mm}$ in diam., sparsely golden hirtellous. Male flowers with a cupulate, 5- to 7-lobed calyx, the lobes $0.5-0.8 \times 0.3-0.8 \mathrm{~mm}$, triangular, sparsely puberulous outside and inside; disc 1.5-1.8 $\mathrm{mm}$ in diam., granularfarinose; stamens 5-7, filaments 3.6-7.0 mm, glabrous, anthers 0.7-1.0 $\times$ 0.4-0.6, ellipsoid; pistillode $0.2-0.5 \mathrm{~mm}$ high, conical, hirtellous. Female flowers with a cupulate, 6-lobed calyx, the lobes c. $0.5 \times 0.4 \mathrm{~mm}$, triangular, sparsely puberulous outside, reflexed with the apex incurved; disc $1.7 \mathrm{~mm}$ in diam., convex, granular-farinose; staminodes 7-8, antherodes ellipsoid; ovary 1.7-1.8 × 1.6-1.8 mm, globose, sparsely strigulose, style 2-1-2.4 mm. Infructescence $7.5-15.2 \mathrm{~cm}, 1.1-2 \mathrm{~mm}$ in diam.; pedicels 3-5 mm in fruit. Fruit spheroid to less often ellipsoid, 14-19 $\mathrm{mm}$ high, $10-17 \mathrm{~mm}$ in diam., apiculate, the apiculum 0.3-0.6 mm, glabrous; fruit wall 0.7-1.1 mm thick; seed discoid, 10-12 $\mathrm{mm}$ in diam., 6-7 $\mathrm{mm}$ thick.

Etymology. - The epithet vulgaris refers to the common, widespread occurrence of the species.

Vernacular names. - "Borasaka", "Lanary Elatrangidina", "Maintipotora”, "Marankoditra”, "Ramaindafa", "Ramendafa".

Conservation status. - Beguea vulgaris is widespread (Fig. 3), with an $\mathrm{EOO}$ of $65,664 \mathrm{~km}^{2}$ and an $\mathrm{AOO}$ probably greater than $2,000 \mathrm{~km}^{2}$ given the amount of potential suitable habitat within the EOO. It occurs in the protected areas of Analamazoatra, Marojejy, Masoala, Ranomafana, Tsitongambarika and Zahamena, and is known from a minimum of 16 locations with respect to the threat of forest degradation and clearing. It is therefore assigned a preliminary assessment of "Least Concern" [LC] using the IUCN Red List criteria (IUCN, 2012).

Notes. - Beguea vulgaris is widely distributed from Marojejy PN to Bemangidy near Tolagnaro (Fig. 3) in mid-elevation humid to subhumid forest. It is easily distinguished from B. apetala by its flat vs folded leaflets, with an obtuse to acute to occasionally short acuminate apex (vs a long acuminate apex), and from B. tsaratananensis by its leaflets with revolute margins and its puberulous sepals (vs flat leaflet margins and glabrous sepals) (Fig. 2D, 12D).

Paratypi.-MAdAgascar. Prov.Antsiranana: SAVA Region, RNI Marojejy, aux env. du sommet d'Ambatosoratra, 14³2'S 4942'30”E, 1583 m, 17-24.VI.1994, fr., Ravelonarivo 234 (MO, P,TAN), ibid. loc., 17-24.VI.1994, fr., Ravelonarivo 253 (MO, P, TAN). Prov. Fianarantsoa: Vatovavy-Fitovinanay Region, Ranomafana

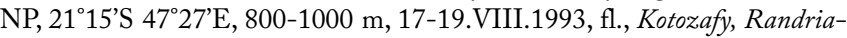
manantena \& Randrianasolo 174 (G, MO, P, TAN); ibid. loc., 21ำ' $16^{\prime} \mathrm{S} 47^{\circ} 25^{\prime} \mathrm{E}$, 


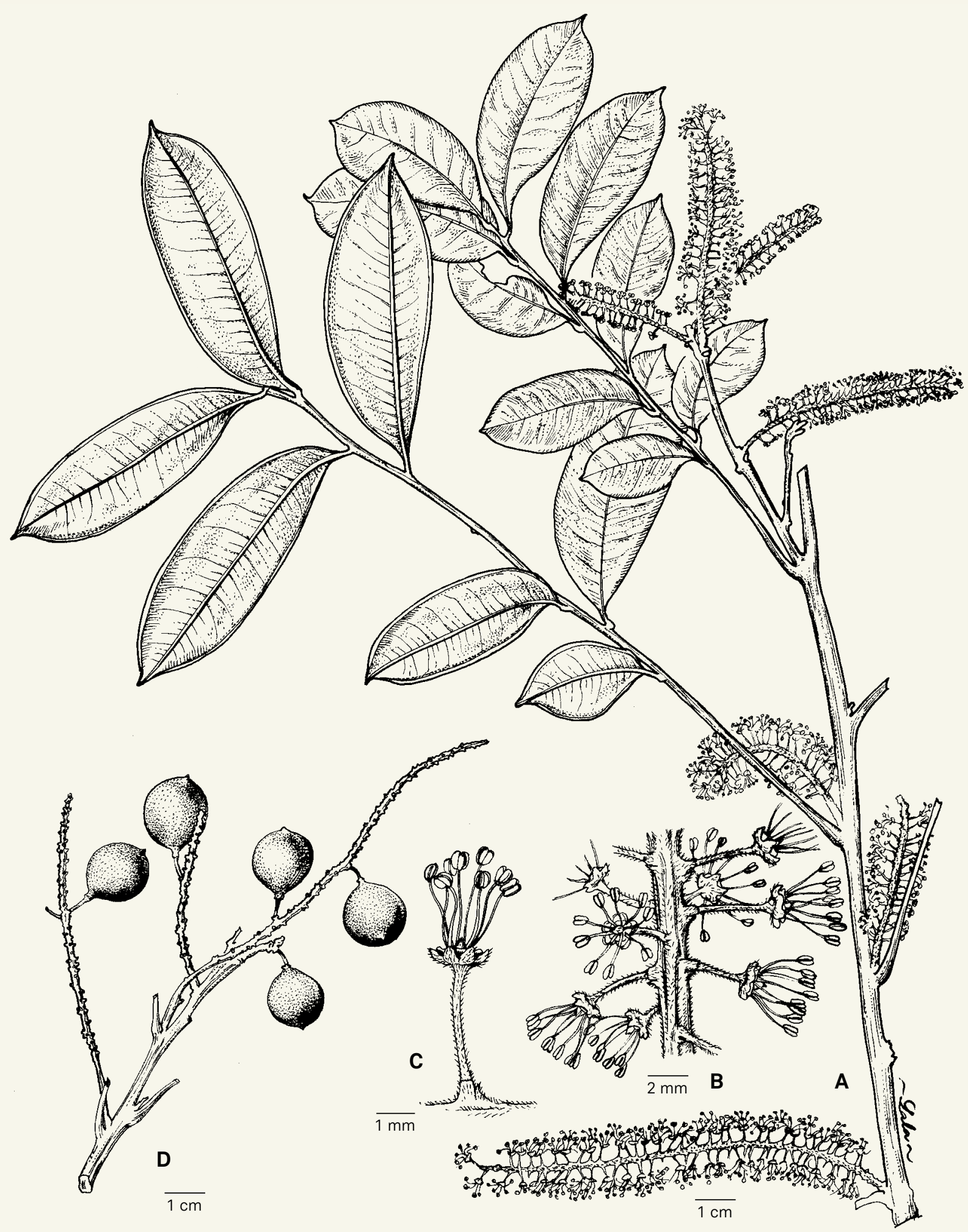

Fig. 12. - Beguea vulgaris G.E. Schatz, Gereau \& Lowry. A. Flowering branch; B. Portion of inflorescence axis; C. Detail of flower at anthesis; D. Infructescence axis with fruits.

[A-C: Malcomber et al. 2058, MO; D: Rakotozafy et al. 174, MO] [Drawing: R.L. Andriamiarisoa] 
900 m, 12 Mar. 1993, fl., Malcomber, Turk $\Xi$ Rakoto 2227 (MO, P,TAN); ibid. loc.,

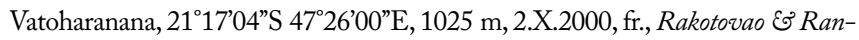
driantafika 987 (MO, P,TAN); ibid. loc., 211'ㅇ 47²5’30”E, 1000 m, 21.II.1991, fl., Schatz et al. 3165 (MO, P, TAN); ibid. loc., parcelle 3, S of National Road 25 at $7 \mathrm{~km}$ W of Ranomafana, Talatakely trail system, $21^{\circ} 15^{\prime} 30^{\prime \prime S} 47^{\circ} 25^{\prime} \mathrm{E}, 950-$ 1150 m, 16.VIII.1993, fl., Turk, Solo \& Randrianasolo 521 (MO, P, TAN); ibid. loc., $21^{\circ} 15^{\prime} \mathrm{S} 47^{\circ} 27^{\prime} \mathrm{E}$, VII.1987, fr., Wright 12 (MO). Prov. Toamasina: Alaotra-Mangoro Region, Moramanga, Ambatovy, forêt d'Analamay, 1849'27'S 48²0'13"E, s.d., fr., Andriatsiferana 2553 (MO, P, TAN); ibid. loc., Ambatovy forest, $18^{\circ} 50^{\prime} 11^{\prime \prime S} 48^{\circ} 18^{\prime} 44^{\prime \prime E}, 1168$ m, 22.I.2007, y.fr., Antilabimena 5175 (MO, P, TAN, TEF); ibid. loc., 1850'14”S 4818'39”E, 1154 m, 19.I.2007, fl., Antilahimena छ Razafindasy 5153 (G, MO, P, TAN); ibid. loc., junction of a road Berano and Analamy, $18^{\circ} 50^{\prime} 08^{\prime \prime S} 48^{\circ} 18^{\prime} 42^{\prime \prime} \mathrm{E}$, 1200 m, 10.III.2007, fr., Antilabimena et al. 5459 (MO, P,TAN); ibid. loc., Ambatovy forest/Andranovery, 18 ${ }^{\circ} 51^{\prime} 53^{\prime \prime S} 48^{\circ} 18^{\prime} 58^{\prime \prime} \mathrm{E}, 1006 \mathrm{~m}$, 5.III.2008, fr., Antilabimena

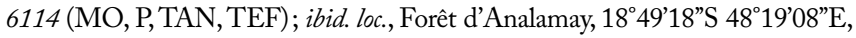
1200 m, 5.VI.2007, fr., Bernard et al. 512 (MO, P,TAN); S de Moramanga, [18 $56^{\circ} \mathrm{S}$ 48 ${ }^{\circ} 13^{\prime} \mathrm{E}$ ], 18.II.1930, fl., Decary 7108 (MO, P); Forêt d'Analamazoatra, [1856'S $48^{\circ} 26^{\prime} \mathrm{E}$ ], 800 m, s.d. \& y.fr., Perrier de la Bâthie 5251 (MO, P); Lakoto, village Bekorakaka, 1903'16”S 4821'43”E, 1000 m, 25.IX.2000, fr., Randrianaivo et al. 546 (MO, P,TAN); forêt d'Ambatovy, 1847'19”S 48²0’33”E, 1009 m, 23.X.2008, ster., Ratolojanahary 41 (MO, TAN); Ambatofitatra, [PN Zahamena], [17 $38^{\circ} 30^{\prime \prime S}$ 48 $\left.{ }^{\circ} 50^{`} \mathrm{E}\right], 14 . X I I .1959$, Al., Réserves Naturelles 10547 (P); Analanjirofo Region, Dist. Vavatenina, Canton Sahatavy, [PN Zahamena], [17³8’30”S 4850’E], 24.II.960, f., Réserves Naturelles 11041 (P,TEF); Alaotra-Mangoro Region, Analamazaotra-Perinet, [1856’S 48²6’E], 20.III.1950, fr., Service Forestier 1159 (P,TEF); Ambatoafo-Moramanga, [19²6’S 48¹2'E], 4.VII.952, fr., Service Forestier 6132 (MO, P, TEF); Analanjirofo Region, env. du col d'Ambatondrama (piste Maroantsetra-Antalaha), au N de la presqu'île Masoala, [1517'30"S 5001’36”E], 600 m, 25.XII.1953, y.fr., Service Forestier 8791 (MO, P, TEF); Alaotra-Mangoro Region, Dist. Moramanga, Malompy, Ambohimiarina, [19 $18^{\prime} \mathrm{S} 48^{\circ} 21^{\prime} \mathrm{E}$ ], 18.IV.957, fr., Service Forestier 16959 (P,TEF); vallée de la Vohomahery, à l'E de Nosivolo (Canton de Manakambahiny-Est) (limite W de la RN III [Zahamena]), [17'46’00”S 48³9'40”E], 27.VIII.1958, fr., Service Forestier 18728 (P, TEF); Ampandroambazaha, PK 28 route Moramanga-Anosibe, [190 $\left.08^{\prime} 30^{\prime} \mathrm{S} 48^{\circ} 15^{\prime} 00^{\prime} \mathrm{E}\right]$, 900 m, 12.VII.1963, fr., Service Forestier 21233 (G, K, MO, P, TEF); Koubaville, entre Moramanga et Anosibe, [19¹6’00”S 48 13’30”E], 23.XII.965, fl., Service Forestier 24414 (MO, P,TEF); Atsinanana Region, Canton et Distr. d'Anosibe An'Ala, [1942'00”S 48 34'00”E], 22.IV.1964, fr., Service Forestier 25005 (K, MO, P,TEF); Ambonitra, PK 39 route Moramanga-Anosibe An'Ala, [19¹0'S 48¹3'E], 5V.1965, fr., Service Forestier 25183 (K, MO, P,TEF); ibid. loc., Service Forestier 25200 (G, K, L, MO, P); Forêt d'Analamazoatra, [1856'S 48 26'E], 3.XII.1934, fl., Ursch 49 (P). Prov. Toliara: Anosy Region, Antsotso, forêt de Bemangidy, 2434'10”S 47 $12^{\prime} 01^{\prime} \mathrm{E}$, 651 m, 5.IV.2008, fl., Randriatafika et al. 834 (MO, P,TAN).

\section{Acknowledgments}

We wish to thank S. Buerki and M. Callmander for helpful comments that improved the paper; S. Andriambololonera and J. Raharimampionona for assistance with specimen and data management; Roger Lala Andriamiarisoa for the fine illustrations; and the staff of the Herbier National in Paris. Field work was conducted under collaborative agreements between the Missouri Botanical Garden and the Parc Botanique et Zoologique de Tsimbazaza and the Direction de la Recherche Forestière et Piscicole, FOFIFA, Antananarivo, Madagascar. We gratefully acknowledge courtesies extended by the Government of Madagascar (Direction Générale de la Gestion des Ressources Forestières) and by Madagascar
National Parks. Part of this research was conducted with support from U.S. National Science Foundation (grant no. DEB-9627072) and the National Geographic Society.

\section{References}

Buerki, S., F. Forest, P. Acevedo-Rodríguez, M.W. Callmander, J.A.A. Nylander, M. Harrington, I. Sanmartín, P. Küpfer $\&$ N. Alvarez (2009). Plastid and nuclear DNA markers reveal intricate relationships at subfamilial and tribal levels in the soapberry family (Sapindaceae). Mol. Phylogen. Evol. 51: 238-258.

Buerki, S., P.P. Lowry II, P.B. Phillipson \& M.W. Callmander (2010). Molecular, phylogenetic and morphological evidence supports recognition of Gereaua, a new endemic genus of Sapindaceae from Madagascar. Syst. Bot. 35: 172-180. DOI: http://dx.doi.org/10.1600/036364410790862669

Buerki, S., R. Doherty, L. Gautier \& M.W. Callmander (2014). Rediscovery of the genus Tsingya Capuron (Sapindaceae) and its phylogenetic position. Candollea 69: 172-180. DOI: http:// dx.doi.org/10.15553/c2014v692a12

Callmander, M.W., C. Rakotovao, J. Razafitsalama, P.B. Phillipson, S. Buerki, C. Hong-Wa, N. Rakotoarivelo, S. Andriambololonera, M.M. Koopman, D.M. Johnson, T. Deroin, A. Ravoahangy, S. Solo, J.-N. Labat \& P.P. Lowry II (2009). New species from the Galoka and Kalebonono massifs: two unknown and severely threatened mountainous areas in NW Madagascar. Candollea 64: 179-202.

Capuron, R. (1969). Révision des Sapindacées de Madagascar et des Comores. Mém. Mus. Natl. Hist. Nat., B, Bot. 19.

Cornet, A. (1974). Essai de cartographie bioclimatique à Madagascar. Notice Explicative No. 55. ORSTOM.

Daly, D.C., J. Raharimampionona \& S. Federman (2015). A revision of Canarium L. (Burseraceae) in Madagascar. Adansonia ser. 3, 37:277-345.

IUCN (2012). IUCN Red List Categories and Criteria: Version 3.1. $2^{\text {nd }}$ ed. IUCN Species Survival Commission, Gland \& Cambridge.

Madagascar Catalogue (2016). Catalogue of the Vascular Plants of Madagascar. Missouri Botanical Garden, St. Louis \& Antananarivo [http://www.tropicos.org/project/mada].

Randrianasolo, A. \& P.P. Lowry II (2009). Four new species and one new combination in the Malagasy endemic genus of Micronychia Oliv. (Anacardiaceae). Adansonia ser. 3, 31: 157-168.

Schatz, G.E. (2000). Endemism in the Malagasy tree flora. In: Lourenço, W.R. \& S.M. Goodman (ed.), Diversity and endemism in Madagascar: 1-9. Mémoires de la Société de Biogéographie, Paris.

Schatz, G.E. (2001). Generic tree fora of Madagascar. Royal Botanic Gardens, Kew and Missouri Botanical Garden, St. Louis. 
